\title{
New $\mathrm{U}-\mathrm{Pb}$ ages and lithochemical attributes of the Ediacaran Rio Doce magmatic arc, Araçuaí confined orogen, southeastern Brazil
}

\author{
Leonardo Gonçalves a,*, Federico Farina ${ }^{a}$, Cristiano Lana ${ }^{a}$, Antônio C. Pedrosa-Soares ${ }^{b}$, \\ Fernando Alkmim ${ }^{a}$, Hermínio A. Nalini Jr. ${ }^{a}$ \\ ${ }^{a}$ Departamento de Geologia, Escola de Minas, Universidade Federal de Ouro, Morro do Cruzeiro, 35400-000 Ouro Preto, MG, Brazil \\ ${ }^{\mathrm{b}}$ Universidade Federal de Minas Gerais, CPMTC-IGC-UFMG, Av. Antônio Carlos 6627, Pampulha, 31270-901 Belo Horizonte, MG, Brazil
}

\section{A R T I C L E I N F O}

Article history:

Received 30 July 2013

Accepted 18 February 2014

\section{Keywords:}

G1 supersuite

Rio Doce arc

Rhyacian basement

Araçuaí-West Congo orogen

\begin{abstract}
A B S T R A C T
The Araçuaí orogen of southeastern Brazil, together with its counterpart located in Africa, the West Congo belt, formed through closure of a gulf connected to the Adamastor Ocean by the end of the Ediacaran and beginning of the Cambrian. Convergence of the margins of the gulf led to the development of the Rio Doce magmatic arc between $630 \mathrm{Ma}$ and $580 \mathrm{Ma}$ on a continental basement mostly composed of Rhyacian orthogneisses. The Rio Doce arc mainly consists of tonalite-granodiorite batholiths, generally crowded with mafic to dioritic enclaves, and minor gabbronorite-enderbite-charnockite plutons, suggesting mixing processes involving crustal and mantle sources. We investigate the basement, magma sources and emplacement ages of the Rio Doce arc. Our data suggest the arc comprises three main granitic rock groups: $i$ ) Opx-bearing rocks mostly of enderbite to charnockite composition; $i i)$ enclaverich tonalite-granodiorite (ETG); and iii) enclave-poor granite-granodiorite with minor tonalite (GT). The Opx-bearing rocks are magnesian, calc-alkalic to alkali-calcic and metaluminous. Together, the ETG and GT rock groups range in composition from tonalite to granite, are metaluminous to slightly peraluminous, show a predominantly medium- to high-K, expanded calc-alkaline signature, and other geochemical and isotopic attributes typical of a pre-collisional volcanic arc formed on a continental margin setting. Mineralogical, chemical, and geochronological data suggest the involvement of HTmelting of granulitic ( $\mathrm{H}_{2} \mathrm{O}$-depleted) sources of Rhyacian age for the generation of Opx-bearing granitic rocks, additionally to magma mixing and fractional crystallization processes. In conclusion, the studied rock groups of the Rio Doce arc were likely formed by interactions of mantle and crustal processes, in an active continental margin setting. These processes involved ascent of mantle magmas that induced partial melting on the continental basement represented by the Rhyacian gneisses.
\end{abstract}

(c) 2014 Elsevier Ltd. All rights reserved.

\section{Introduction}

The Araçuaí orogen (SE Brazil) and its counterpart located in Africa, the West Congo belt, represent a branch of the Brasiliano Pan-African orogenic network (Fig. 1) formed during the amalgamation of West Gondwanaland by the end of the Neoproterozoic (Trompette, 1994; Brito Neves et al., 1999). In contrast to typical plate margin orogens, the Araçuaí - West Congo orogenic system developed inside an embayment of the São Francisco-Congo

\footnotetext{
* Corresponding author. Tel.: +55 31.87101840 .

E-mail addresses: leonardo@degeo.ufop.br, leonardogeologo@hotmail.com (L. Gonçalves), fannak@gmail.com (F. Farina), cristianodeclana@gmail.com (C. Lana), pedrosa@pq.cnpq.br (A.C. Pedrosa-Soares), ffalkmim@gmail.com (F. Alkmim), herminio.nalini@gmail.com (H.A. Nalini).
}

palaeocontinent, i.e., a gulf-like basin, partially floored by ocean crust and connected to the Adamastor Ocean (Pedrosa-Soares et al., 1992, 1998, 2001, 2008; Cordani et al., 2003; Alkmim et al., 2006). Such a peculiar geotectonic scenario, together with the occurrence of ophiolites and a pre-collisional magmatic arc, inspired the concept of a confined orogen (Pedrosa-Soares et al., 2001), as an intermediate term between the typical continental margin or intercratonic orogens, and the wholly ensialic intracontinental orogens or inverted aulacogens (Rogers and Santosh, 2004).

Despite this confined environment, the Araçuaí orogen shows a well-developed calc-alkaline magmatic arc, the Rio Doce arc, which occupies an area of over 20,000 $\mathrm{km}^{2}$ (Figueiredo and Campos Neto, 1993; Nalini Jr. et al., 2005; Pedrosa-Soares and WiedemannLeonardos, 2000; De Campos et al., 2004; Martins et al., 2004; Gonçalves et al., 2010; Novo et al., 2010; Pedrosa-Soares et al., 2011). 


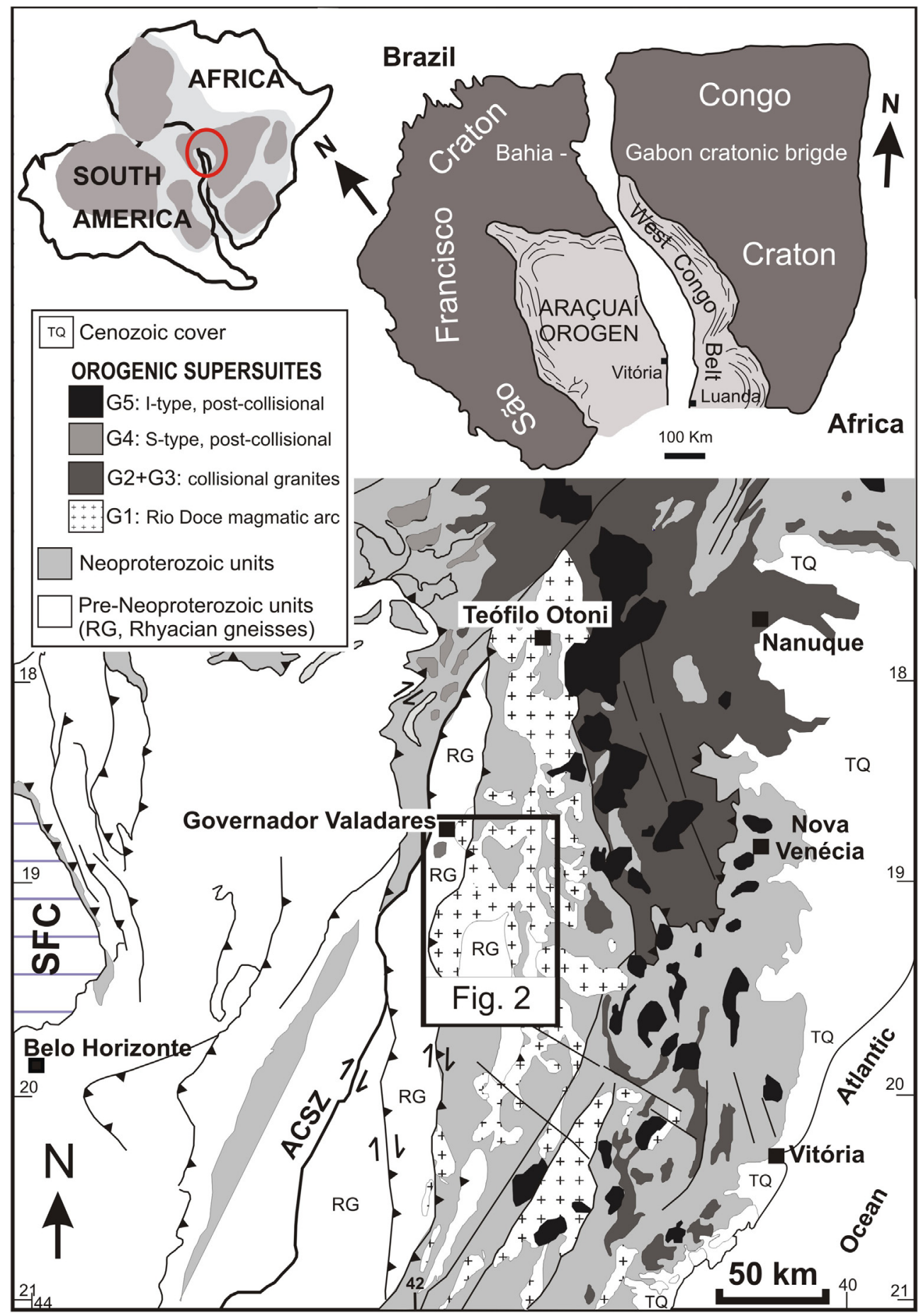

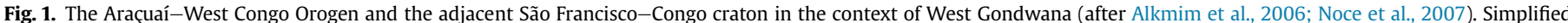

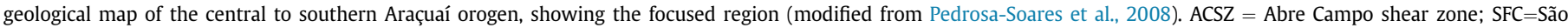
Francisco Craton.

Central to a systematic reconstruction of the Rio Doce arc is the determination of its chemical and isotopic variations that would lead to a much clearer understanding of the magmatic processes involved in the pre-collisional phase of the orogen, and of the nature of the sources involved in the formation of the granitoids. In this paper, we provide field/petrographic observations, major and trace element data, and zircon $\mathrm{U}-\mathrm{Pb}$ ages to characterize the geochemical diversity of I-type rocks that comprise the Rio Doce arc. We also combine the new geochemical and geochronological dataset with previously published data to discuss the magmatic processes and possible sources involved in the genesis of the arc granitoids.

The study area, located between Governador Valadares and Ipanema in eastern Minas Gerais State, Brazil, was selected based on the fact that it is well covered by systematic geological mapping, contains many of the best exposures of plutons forming the Rio 
Doce arc and, consequently exposes a wide variety of magmatic rocks, representative of much of the arc. Geological maps, mostly from systematic mapping projects in the 1:100,000 scale, covering the study area have been published since the 1960's (Barbosa et al., 1964, 1966; Vieira, 1993, 2000; Féboli, 2000; Féboli and Paes, 2000; Ribeiro, 2000; Signorelli, 2000; Tuller, 2000; Oliveira, 2000). Our integrated map (Fig. 2) resulted from a thorough compilation of those maps, assisted by a large amount of carefully detailed descriptions from our own field-based work and petrographic studies, providing a consistent geological basis for the presented studies. The compiled geochemical and geochronological datasets were collected from many outcrops (tens of kilometers apart) and they are useful to outline regional geochemical features, concerning a general model for the petrogenesis of the Rio Doce arc.

\section{Geological setting}

The evolution of the Araçuaí orogen lasted from the Early Ediacaran up to the Cambrian-Ordovician boundary, and produced igneous rocks that are currently exposed from shallow to deep crustal levels over an area of $350,000 \mathrm{~km}^{2}$ (Fig. 1). Based on field relationships, structural features, geochemical and geochronological data, granitic rocks from this orogen, including their Opxbearing (charnockitic) equivalents and associated mafic rocks, have been grouped into five supersuites, the G1, G2, G3, G4 and G5 (Pedrosa-Soares et al., 2011).

The G1 Supersuite represents the plutonic component of the Rio Doce magmatic arc (Fig. 1). G1 plutons intruded the Rhyacian basement and are associated with metamorphosed pyroclastic and volcanoclastic rocks of dacitic and rhyolitic composition of the Rio Doce Group, forming a roughly NS-trending and $55 \mathrm{~km}$ wide belt that extends for over $300 \mathrm{~km}$ along the eastern part of the orogen (Nalini Jr. et al., 2000; Pedrosa-Soares et al., 2001, 2011; Vieira, 2007; Gonçalves et al., 2010). It mainly consists of medium- to high$\mathrm{K}$, calc-alkaline, tonalitic to granitic bodies, and their Opx-bearing equivalents, generally crowded with mafic to dioritic facies and enclaves (Nalini Jr. et al., 2000; Gonçalves et al., 2010; PedrosaSoares et al., 2011), and a few mafic to intermediate plutons rich in gabbroic to enderbitic facies (Novo et al., 2010; Tedeschi, 2013). The zircon $\mathrm{U}-\mathrm{Pb}$ crystallization ages of the $\mathrm{G} 1$ Supersuite range predominantly from $630 \mathrm{Ma}$ to $580 \mathrm{Ma}$, predating the ages of emplacement of syn-collisional, S-type granites (G2 Supersuite) between 582 and $560 \mathrm{Ma}$ (Nalini Jr. et al., 2000; Pedrosa-Soares et al., 2008, 2011; Silva et al., 2005, 2011). All these features, together with the pre-collisional, volcanic arc signature of G1 rocks, led several authors to interpret this supersuite as forming a continental magmatic arc (e.g., Nalini Jr. et al., 2000, 2005; PedrosaSoares and Wiedemann-Leonardos, 2000; Pedrosa-Soares et al., 2001, 2008, 2011; Martins et al., 2004; Gonçalves et al., 2010; Novo et al., 2010; Tedeschi, 2013), named Rio Doce arc by Figueiredo and Campos-Neto (1993). This arc seems to have been formed in response to subduction of oceanic lithosphere from west to east (present day geography), between $630 \mathrm{Ma}$ and $580 \mathrm{Ma}$, i.e., before the collisional event that led to the full development of the Araçuaí-West Congo orogen at around 575-560 Ma (PedrosaSoares et al., 1998, 2001, 2008; Alkmim et al., 2006).

The basement of the Rio Doce arc mainly comprises the Rhyacian orthogneisses of the Juiz de Fora Complex, cropping out along the southern and southwestern portions of the arc, and the Pocrane Complex, exposed in the central-southern and northwestern arc sectors (Fig. 1).

The Juiz de Fora Complex consists essentially of green-grayish, banded, granulitic gneisses of enderbite to charnockite composition with intercalations of mafic granulites, representing a calcalkaline suite with minor tholeiitic rocks. Although the Opx- bearing rocks are generally free or poor in biotite, this mineral can replace pyroxenes and hornblende along shear zones. OpxGrd-bearing granitic leucosomes and small plutons (the so-called garnet charnockite) occur as product of partial melting of the Juiz de Fora enderbitic gneisses, during the Brasiliano orogeny. Zircon $\mathrm{U}-\mathrm{Pb}$ age determinations on the Juiz de Fora gneisses constrain its crystallization age between $2.2 \mathrm{Ga}$ and $2.0 \mathrm{Ga}$ (Table 1). Positive to close to zero epsilon Nd values, and the absence of inherited zircon grains characterize the Juiz de Fora Complex as part of a juvenile magmatic arc (Figueiredo and Teixeira, 1996; Machado et al., 1996; Duarte et al., 1997, 2000; Costa, 1998; Fischel et al., 1998; Noce et al., 2007, 2012; Heilbron et al., 2010; Novo et al., 2010). The Rhyacian (2.2-2.08 Ga) Pocrane Complex consists of poorly to nonmigmatized, banded to laminated, biotite-hornblende orthogneisses of dioritic to granitic composition, representing a calcalkaline series metamorphosed in the amphibolite facies (Féboli and Paes, 2000; Pereira and Zuchetti, 2000; Tuller, 2000; Novo, 2013). The Pocrane Complex also lacks in inherited zircon grains and shows positive epsilon Nd values, representing a less metamorphic (upper crustal level) correlative of the juvenile Juiz de Fora Complex (Novo, 2013).

\section{Analytical methods}

Whole rock geochemical analyses were conducted on 25 samples of the least deformed plutonic rocks of the G1 Supersuite granitoids. All the samples were crushed and milled at the Departamento de Geologia of the Universidade Federal de Ouro Preto (Brazil). Major and trace element concentrations were determined using Inductively Coupled Plasma Atomic Emission (ICP-AES) and Mass (ICP-MS) Spectrometry, respectively, at the ACME Analytical Laboratory LTDA, Vancouver, Canada. Detection limits are $0.01 \%$ for oxides and $0.1 \mathrm{ppm}$ for most trace elements, reaching values up to $0.01 \mathrm{ppm}$ for Heavy Rare Earth Elements, such as Tb, Tm and Lu. The 25 samples from this study (Table 2) were combined with 144 published rock compositions from the G1 Supersuite, exposed between the towns of Teófilo Otoni and Juiz de Fora. These 144 samples were grouped according to the three groups individualized in this study, presented in detailed in the following section. The dataset of samples from the literature is presented as Supplementary Data - Item 1. The compiled dataset covers the outcrop map area of the Rio Doce magmatic arc and represents approximately $30 \%$ of the recognized magmatism in the Araçuaí orogen (Fig. 1).

$\mathrm{U}-\mathrm{Pb}$ zircon LA-ICP-MS analyses were carried out at the Isotope Geochemistry Laboratory of the Departamento de Geologia of the Universidade Federal de Ouro Preto (Brazil), and the results are presented as Supplementary Data - Item 2. Zircon grains were hand-picked and mounted on adhesive tape, enclosed in epoxy resin and then polished and photographed in transmitted light. Extensive use of cathodoluminescence $(\mathrm{CL})$ imaging was made in order to identify internal structures and choose potential target sites for $\mathrm{U}-\mathrm{Pb}$ analyses. The mounts were then cleaned and the $\mathrm{U}-$ $\mathrm{Pb}$ isotopic compositions of zircon were analyzed by using an Agilent 7700 ICP-MS and $213 \mathrm{~nm}$ laser ablation system of the Departamento de Geologia of the Universidade Federal de Ouro Preto (Brazil). Spot laser ablation was adopted in this study with a beam size of $40 \mu \mathrm{m}$ and laser pulse frequency of $10 \mathrm{~Hz}$. For details on the LA-ICP-MS methods and running conditions refer to Appendix I.

\section{Sampling, petrography and field relationships}

Based on our field, petrographic and geochemical data, as well as on compiled information from the literature, the rocks forming 


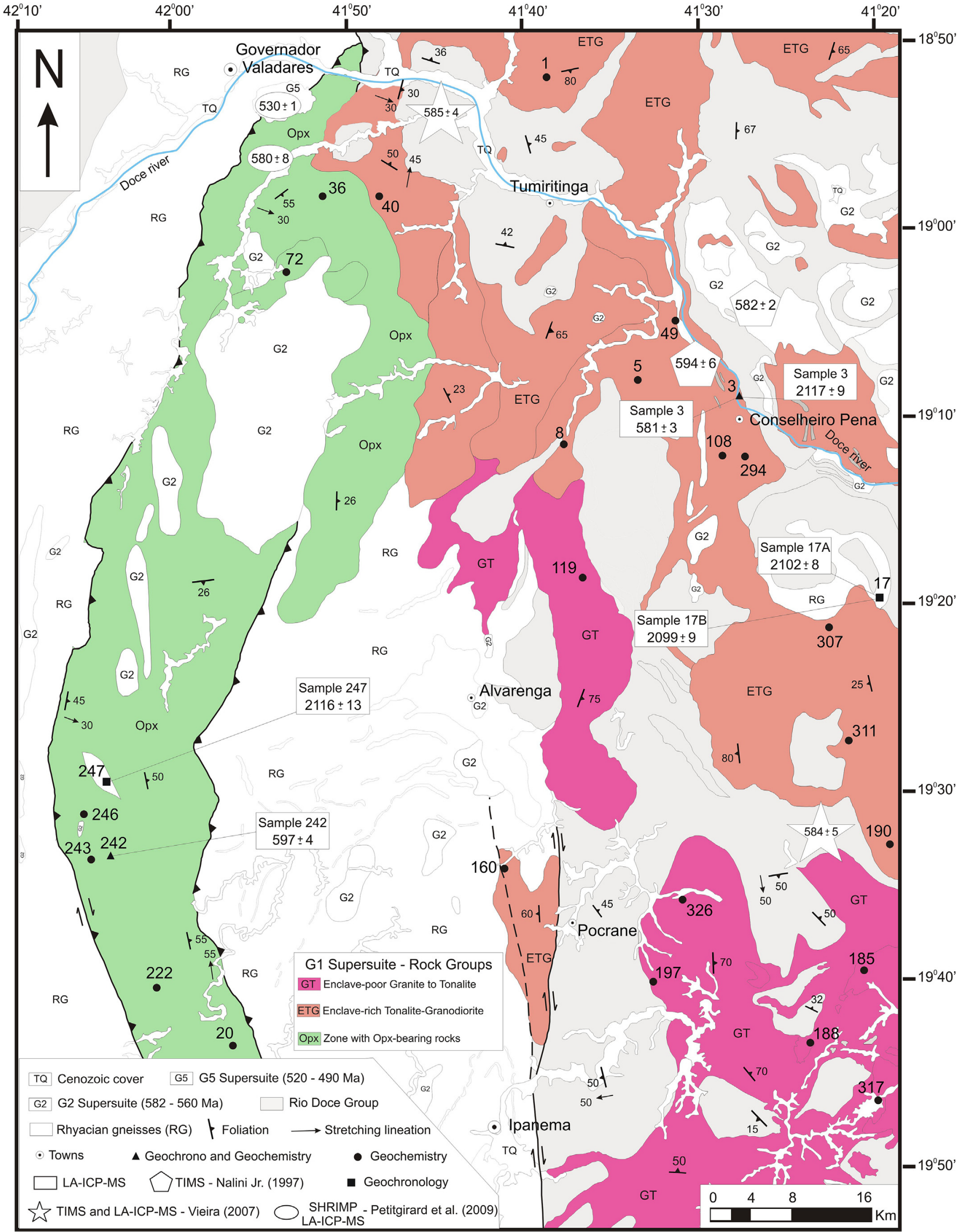

Fig. 2. Geological map of the study area showing the sample sites for geochemical and geochronological analyses. Modified from Gonçalves et al., 2010. 
Table 1

Main features and crystallization ages of plutons belonging to the G1 Supersuite and basement rocks.

\begin{tabular}{|c|c|c|c|c|c|}
\hline Local name & Petrography & Structure & Age (Ma) & Technique & References \\
\hline Derribadinha & $\begin{array}{l}\text { Biotite-bearing tonalitic-granitic } \\
\text { gneiss }\end{array}$ & $\begin{array}{l}\text { Strongly foliated to } \\
\text { banded }\end{array}$ & $\begin{array}{l}561 \pm 8 \text { (anatetic overgrowth) } \\
\sim 2100 \text { (inherited grains) }\end{array}$ & $\begin{array}{l}\text { Zircon } \mathrm{U}-\mathrm{Pb} \\
\text { SHRIMP }\end{array}$ & Silva et al. (2011) \\
\hline Derribadinha & $\begin{array}{l}\text { Tonalite with associated granitic } \\
\text { veins }\end{array}$ & $\begin{array}{l}\text { Isotropic to slightly } \\
\text { foliated }\end{array}$ & $\begin{array}{l}580 \pm 8 \\
\sim 2100 \text { (inherited grains) }\end{array}$ & $\begin{array}{l}\text { Zircon U-Pb } \\
\text { LA-ICP-MS }\end{array}$ & $\begin{array}{l}\text { Petitgirard et al. (2009) } \\
\text { Mondou et al. (2012) }\end{array}$ \\
\hline Divino Suite & $\begin{array}{l}\text { Charnockite of monzodioritic } \\
\text { composition }\end{array}$ & $\begin{array}{l}\text { Slightly to strongly } \\
\text { foliated }\end{array}$ & $592 \pm 7$ and $595 \pm 4$ & $\begin{array}{l}\text { Zircon U-Pb } \\
\text { LA-ICP-MS }\end{array}$ & Novo (2009) \\
\hline Galiléia & $\begin{array}{l}\text { Tonalites, granodiorites and granites } \\
\text { with associated mafic enclaves }\end{array}$ & Foliated to isotropic & $\begin{array}{l}594 \pm 6 \\
\sim 2100 \text { (inherited grains) }\end{array}$ & $\begin{array}{l}\text { Zircon } \mathrm{U}-\mathrm{Pb} \\
\text { TIMS }\end{array}$ & Nalini Jr. (1997) \\
\hline Manhuaçú & $\begin{array}{l}\text { Biotite-hornblende tonalite with } \\
\text { mafic and dioritic enclaves }\end{array}$ & $\begin{array}{l}\text { Isotropic to slightly } \\
\text { foliated }\end{array}$ & $597 \pm 3$ & Zircon $\mathrm{U}-\mathrm{Pb}$ & $\begin{array}{l}\text { Pedrosa-Soares } \\
\text { et al. (2011) }\end{array}$ \\
\hline Muniz Freire & Tonalite & Foliated & $588 \pm 4$ & LA-ICP-MS & \\
\hline Muriaé Batholith & Porphyritic granite to tonalite & Isotropic to foliated & $593 \pm 4$ & $\begin{array}{l}\text { Zircon U-Pb } \\
\text { LA-ICP-MS }\end{array}$ & Figueiredo (2009) \\
\hline Chapada do Bueno & Tonalite & Foliated to banded & $625+11$ & $\begin{array}{l}\text { Single zircon } \\
\mathrm{Pb}-\mathrm{Pb} \text { evaporation }\end{array}$ & Paes (1999) \\
\hline $\begin{array}{l}\text { Derribadinha } \\
\text { sample } 242 \\
\end{array}$ & Tonalite & Foliated & $\begin{array}{l}597 \pm 4 \\
\sim 2100 \text { (inherited grains) }\end{array}$ & $\begin{array}{l}\text { Zircon U-Pb } \\
\text { LA-ICP-MS }\end{array}$ & This study \\
\hline $\begin{array}{l}\text { Galiléia } \\
\text { sample } 3 \\
\end{array}$ & Quartz diorite enclave & Foliated & $\begin{array}{l}581 \pm 3 \\
2117 \pm 9 \text { (inherited grains) }\end{array}$ & $\begin{array}{l}\text { Zircon U-Pb } \\
\text { LA-ICP-MS }\end{array}$ & This study \\
\hline Frei Inocêncio gneiss & $\begin{array}{l}\text { Biotite-hornblende orthogneiss } \\
\text { with associated mafic enclaves } \\
\text { and leucocratic veins }\end{array}$ & $\begin{array}{l}\text { Migmatized, foliated } \\
\text { to banded }\end{array}$ & $\begin{array}{l}2122 \pm 11 \\
565 \pm 7 \text { (overgrowth) }\end{array}$ & $\begin{array}{l}\text { Zircon U-Pb } \\
\text { SHRIMP }\end{array}$ & Silva et al. (2011) \\
\hline Juiz de Fora complex & Charnockite gneiss & Slightly foliated & 2134 & $\begin{array}{l}\text { Zircon } \mathrm{U}-\mathrm{Pb} \\
\text { TIMS }\end{array}$ & Machado et al. (1996) \\
\hline Juiz de Fora complex & $\begin{array}{l}\text { Enderbitic gneiss with } \\
\text { charnockite veins }\end{array}$ & Migmatized, banded & $2084 \pm 13$ & $\begin{array}{l}\text { Zircon U-Pb } \\
\text { SHRIMP }\end{array}$ & Noce et al. (2007) \\
\hline $\begin{array}{l}\text { Juiz de Fora complex } \\
\text { sample } 247\end{array}$ & Enderbite & $\begin{array}{l}\text { Isotropic to slightly } \\
\text { foliated }\end{array}$ & $2116 \pm 13$ & $\begin{array}{l}\text { Zircon U-Pb } \\
\text { LA-ICP-MS }\end{array}$ & This study \\
\hline $\begin{array}{l}\text { Pocrane complex } \\
\text { sample } 17\end{array}$ & Tonalitic gneiss & Banded rock & $\begin{array}{l}2102 \pm 8 \\
2099 \pm 9\end{array}$ & $\begin{array}{l}\text { Zircon U-Pb } \\
\text { LA-ICP-MS }\end{array}$ & This study \\
\hline
\end{tabular}

the G1 Supersuite in the study area can be subdivided into three rock groups, namely (Fig. 2): i) Opx-bearing rocks, ii) enclave-rich tonalite-granodiorite (ETG), and iii) enclave-poor granite to tonalite (GT). These rock groups form batholitic masses, and do not represent necessarily individual plutons (in fact, detailed studies of individual plutons are still rare in the Rio Doce arc, and an example can be found in Tedeschi, 2013). All these rock groups include variable amounts of mafic to intermediate enclaves and facies. Similar rock groups have been recognized elsewhere in the Rio Doce arc, e.g., the Divino Suite composed of Opx-bearing rocks from gabbronorite to charnockite composition (Novo et al., 2010), the Manhuaçu Tonalite rich in mafic to dioritic enclaves (Noce et al., 2006; Pedrosa-Soares et al., 2011), and those recently studied by Tedeschi (2013), the Chaves Enderbite rich in gabbronorite facies and enclaves, the Brasilândia Tonalite rich in mafic enclaves, and the enclave-poor Guarataia Granodiorite.

In the study area, the zone with Opx-bearing rocks occurs along the western sector, forming a NS-elongated thrust slice sandwiched between Rhyacian orthogneisses of distinct metamorphic facies: to the west, the granulitic Juiz de Fora Complex and, to the east, the amphibolite facies Pocrane Complex (Fig. 2). The dominant rock unit occurring along this zone is the Derribadinha Tonalite, a gneissic rock with common migmatitic and mylonitic structures, ranging in composition from tonalite to granite (Féboli, 2000; Féboli and Paes, 2000; Pereira and Zucchetti, 2000; Ribeiro, 2000; Signorelli, 2000; Gonçalves, 2009; Silva et al., 2011). The Derribadinha batholith contains a large number of small bodies of Opx-bearing rocks which are predominantly greenish, fine- to medium-grained enderbites, and minor diorites and gabbros. The studied Opx-bearing rocks consist in average of quartz $(\sim 30 \%)$, plagioclase $(\sim 25 \%)$, microcline $(\sim 15 \%)$, and up to $30 \%$ of total mafic minerals (orthopyroxene, clinopyroxene, hornblende and biotite). Titanite, zircon, allanite, garnet, pyrrhotite, chalcopyrite, pyrite, pentlandite are common accessories. Although Opx-bearing rocks locally show preserved igneous features, in most cases they display a solid-state metamorphic foliation marked by the alignment of hornblende and/or biotite. The brown-reddish biotite is, occasionally, a product of hornblende breakdown. Hornblende defines the rock foliation, but also occurs without shape preferred orientation. Igneous orthopyroxene is commonly replaced by hornblende and/or biotite (Fig. 3a and b). Feldspar grains, mostly plagioclase, show undulose extinctions, mechanical twinning and recrystallized grains. Quartz shows evidence of solid-state deformation, such as elongated grains, undulose extinctions, deformation bands, recrystallized grains, ribbons and subgrains in chessboard pattern.

The main field characteristic of the enclave-rich tonalitegranodiorite rock group (ETG) is the outstanding presence of $\mathrm{cm}$ - to m-long melanocratic to mesocratic enclaves (Fig. 4a), with compositions ranging from gabbro to tonalite. These ETG rocks are exposed as large elongated bodies in the central and eastern parts of the study area, and they are the most common rock-assemblage within the Rio Doce arc (the so-called Galiléia, São Vitor and similar tonalitic batholiths; Féboli, 2000; Vieira, 2000; Féboli and Paes, 2000; Oliveira, 2000; Tuller, 2000). The studied rocks are light to dark gray, medium to coarse-grained, and composed in average of plagioclase $(\sim 40 \%)$, quartz $(\sim 35 \%)$, biotite $(\sim 12 \%)$, orthoclase ( $\sim 5 \%)$, microcline $(\sim 5 \%)$ and hornblende $(\sim 3 \%)$. Garnet, titanite, allanite, apatite, rutile, ilmenite, magnetite, pyrrhotite and chalcopyrite are common accessory minerals. Muscovite and clinozoisite are secondary products of plagioclase breakdown, whilst chlorite forms as replacement of biotite. Quartz shows elongated grains, undulose extinction, subgrains or recrystallized grains, as well as triple grain junctions. Feldspars show mechanical twinning, undulose extinction, or recrystallized grains, although plagioclase grains with concentric zoning, possibly with calcium-rich core, are visualized indicating preserved igneous features.

The enclaves and their host granitoids have similar mineral compositions, but different mineral proportions. The enclaves, that locally exhibit chilled margins, consist of biotite, hornblende, zoned 
Table 2

Selected major and trace element data for the analyzed rock groups of the G1 Supersuite in the study area.

\begin{tabular}{|c|c|c|c|c|c|c|c|c|c|c|c|c|c|c|c|c|c|c|c|c|c|c|c|c|c|}
\hline \multirow[b]{2}{*}{ Sample } & \multicolumn{7}{|c|}{ Opx-bearing group } & \multicolumn{10}{|c|}{ Enclave-rich tonalite and granodiorite (ETG group) } & \multicolumn{8}{|c|}{ Enclave-poor granite to tonalite (GT group) } \\
\hline & L243 & L072 & L222 & L242 & L036 & L020 & L246 & L108 & L160 & L005 & L040 & L008 & L003 & L049 & L307 & L001 & L294 & L185 & L317 & L326 & L190 & L197 & L311 & L188 & L119 \\
\hline \multicolumn{26}{|c|}{ Major element (wt.\%) } \\
\hline $\mathrm{SiO}_{2}$ & 56.44 & 59.89 & 61.31 & 1.82 & .93 & 62.48 & 6.61 & 63.98 & 66.06 & 66.56 & 67.94 & 67.90 & 67.86 & 68.50 & 69.79 & 1.79 & 72.80 & 62.69 & 66.11 & 67.31 & 70.65 & 71.94 & 72.15 & 75.48 & 76.18 \\
\hline $\mathrm{TiO}_{2}$ & 0.77 & 0.95 & 1.01 & 0.97 & 0.78 & 1.06 & 0.43 & 0.69 & 0.53 & 0.57 & 0.43 & 0.62 & 0.51 & 0.47 & 0.37 & 0.26 & 0.30 & 0.87 & 0.59 & 0.57 & 0.33 & 0.31 & 0.24 & 0.14 & 0.12 \\
\hline $\mathrm{Al}_{2} \mathrm{O}_{3}$ & 16.08 & 18.87 & 16.67 & 14.23 & 17.32 & 16.56 & 15.80 & 16.74 & 16.87 & 16.16 & 16.50 & 15.19 & 15.49 & 15.42 & 15.58 & 14.55 & 13.76 & 16.76 & 16.72 & 15.70 & 14.99 & 14.20 & 15.07 & 13.15 & 12.58 \\
\hline $\begin{array}{r}\mathrm{Fe}_{2} \mathrm{O}_{3} \\
\text { tot }\end{array}$ & 9.64 & 5.67 & 8.14 & 9.64 & 6.65 & 5.82 & 4.73 & 6.21 & 5.14 & 5.32 & 4.18 & 5.56 & 5.11 & 4.31 & 3.81 & 3.06 & 3.61 & 6.60 & 4.58 & 4.91 & 3.31 & 2.77 & 1.80 & 1.56 & 2.47 \\
\hline $\mathrm{MgO}$ & 4.40 & 2.18 & 2.77 & 2.81 & 2.02 & 2.06 & 2.09 & 1.82 & 1.08 & 1.40 & 0.82 & 1.53 & 1.30 & 1.23 & 0.61 & 0.68 & 0.62 & 1.82 & 1.20 & 1.33 & 0.70 & 0.63 & 0.59 & 0.27 & 0.07 \\
\hline MnO & 0.15 & 0.05 & 0.15 & 0.19 & 0.08 & 0.10 & 0.07 & 0.09 & 0.06 & 0.07 & 0.06 & 0.06 & 0.08 & 0.08 & 0.05 & 0.04 & 0.05 & 0.12 & 0.06 & 0.09 & 0.06 & 0.02 & 0.02 & 0.04 & 0.04 \\
\hline $\mathrm{CaO}$ & 2 & 5.51 & 3.02 & 5.16 & 6.52 & 3.88 & 4.83 & 5.20 & 4.63 & 4.51 & 5.55 & 3.63 & 4.13 & 4.54 & 4.16 & 3.03 & 2.97 & 4.88 & 4.54 & 4.03 & .94 & 1.15 & 1.21 & 1.54 & 1.84 \\
\hline $\mathrm{Na}_{2} \mathrm{O}$ & 3.75 & 3.93 & 2.36 & 4.09 & 3.06 & 3.67 & 3.50 & 2.77 & 3.60 & 2.81 & 3.40 & 3.05 & 2.71 & 2.81 & 3.50 & 2.84 & 2.74 & 3.16 & 3.44 & 3.11 & 52 & 2.50 & 3.67 & 2.89 & 3.38 \\
\hline $\mathrm{K}_{2} \mathrm{O}$ & 1.68 & 2.4 & 4.39 & 0.86 & 1.45 & 3.90 & 1.83 & 2.32 & 1.87 & 2.45 & 1.01 & 2.19 & 2.68 & 2.49 & 2.03 & 3.63 & 3. & 2.8 & 2.5 & 2.79 & & 6.25 & 5.15 & 39 & 3.29 \\
\hline $\mathrm{P}_{2} \mathrm{O}_{5}$ & 0.28 & 0.47 & 0.18 & 0.22 & 0.19 & 0.47 & 0.11 & 0.17 & 0.16 & 0.14 & 0.11 & 0.27 & 0.13 & 0.14 & 0.09 & 0.13 & 0.09 & 0.24 & 0.18 & 0.16 & 13 & 0.23 & 0.09 & .04 & 0.03 \\
\hline L.O.I & 0.40 & 1.00 & & & 0.30 & & 060 & & 0.40 & م10 & 0.70 & & 040 & 0.40 & 100 & 080 & 0.40 & 050 & (8) & 0.20 & 0.30 & 0.30 & 060 & 00 & 0.20 \\
\hline \multicolumn{26}{|c|}{ Major element (molar \%) } \\
\hline $\mathrm{A} / \mathrm{CNK}$ & 0.80 & 1.01 & 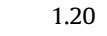 & 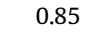 & 95 & 9 & 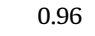 & 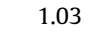 & 1.04 & 1.06 & 0.99 & 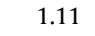 & .05 & 1.00 & 1.01 & .04 & 1.0 & 0.99 & 1.01 & $1.0^{-}$ & 03 & 12 & 1.10 & .03 & 1.01 \\
\hline Mg\# & & 0.43 & 0.40 & .37 & 0.38 & 0.41 & 0.47 & 0.37 & 0.29 & 0.34 & 0.28 & 0.35 & 0.33 & 0.36 & 0.24 & 0.30 & 0.25 & 0.35 & 0.34 & 0.35 & 0.30 & 0.31 & 0.40 & 0.26 & 0.05 \\
\hline \multicolumn{26}{|c|}{ Trace element (ppm) } \\
\hline $\mathrm{Ni}$ & 14.00 & 10.60 & 20 & 21.60 & 4.80 & 10 & .70 & 7.80 & 3.60 & 1.80 & 2.90 & 80 & .30 & 8.10 & 1.90 & 2.20 & 3.20 & 4.00 & 2.60 & 2.20 & 1.40 & 3.30 & 8.60 & 1.20 & 1.50 \\
\hline $\mathrm{v}$ & 168.00 & 92.00 & 114.00 & 145.00 & 105.00 & 97.00 & 69.00 & 83.00 & 44.00 & 67.00 & 44.00 & 73.00 & 61.00 & 58.00 & 29.00 & 19.00 & 28.00 & 94.00 & 53.00 & 65.00 & 30.00 & 13.00 & 11.00 & 12.00 & 8.00 \\
\hline Ta & 0.5 & 0.7 & 0.7 & 0.8 & 0.3 & 1.2 & 0.3 & 0.7 & 0.5 & 0.8 & 0.3 & 1.3 & 0.6 & 1.0 & 0.3 & 0.7 & 0.5 & 0.9 & 0.3 & 0.8 & 0.5 & 0.6 & 0.3 & 0.4 & 0.5 \\
\hline $\mathrm{Sr}$ & 546.3 & 374.3 & 641.8 & 189.0 & 349.8 & 315.2 & 499.8 & 216.8 & 337.0 & 215.3 & 346.4 & 209.9 & 189.6 & 195.3 & 293.1 & 205.6 & 175.9 & 334.0 & 436.3 & 355.0 & 265.9 & 159.0 & 199.2 & 203.6 & 189.9 \\
\hline Th & 0.9 & 0.6 & 14.3 & 1.2 & 1.4 & 3.3 & 0.8 & 7.6 & 11.6 & 12.6 & 8.1 & 6.4 & 11.2 & 8.0 & 10.1 & 10.3 & 11.6 & 9.2 & 8.3 & 8.5 & 6.8 & 20.9 & 12.2 & 6.0 & 10.6 \\
\hline $\mathrm{Rb}$ & 51.0 & 102.0 & 133.6 & 9.9 & 45.1 & 217.2 & 58.7 & 81.3 & 85.1 & 88.3 & 25.6 & 91.3 & 92.4 & 76.5 & 52.7 & 112.8 & 76.1 & 89.4 & 61.8 & 75.6 & 87.0 & 226.2 & 157.8 & 109.3 & 57.3 \\
\hline $\mathrm{Ba}$ & 603 & 673 & 1765 & 113 & 770 & 1069 & 296 & 579 & 438 & 599 & 528 & 609 & 576 & 488 & 207 & 766 & 963 & 248 & 2037 & 730 & 317 & 924 & 395 & 1089 & 2283 \\
\hline $\mathrm{Nb}$ & 10.8 & 15.0 & 14.1 & & 9.9 & 26.8 & 8.3 & 11.4 & 12.6 & 12.2 & 8.5 & 18.1 & 11.5 & 9.8 & 87 & 8.2 & 10.8 & 14.9 & 10.0 & 8.7 & 8.1 & 9.7 & 6.8 & 6.7 & 8.5 \\
\hline U & 0. & 1.0 & 3 & & 0. & & 0. & 1 & 0.9 & 1.3 & 0.6 & 1 & 1. & 3.1 & & 2.0 & 1. & 1 & 0.9 & 1.9 & 1.1 & 3.9 & 1.5 & 1.3 & 1.4 \\
\hline $\mathrm{Zr}$ & 136.5 & 224.4 & 364.3 & 194.4 & 238.3 & 298.2 & 91.9 & 206.1 & 213.1 & 179.7 & 334.6 & 285.2 & 201.4 & 169.0 & 211.6 & 154.2 & 171.3 & 328.6 & 74.3 & 125.5 & 151.0 & 227.1 & 08.1 & 88.3 & 187.0 \\
\hline Y & & 15.5 & & & & & 78 & & 10.4 & 19.6 & 22.2 & & 214 & 29.2 & 180 & 155 & 16 & & 132 & 16.5 & 16.4 & 27.1 & 39 & 95 & 27.8 \\
\hline $\mathrm{La}$ & 30.8 & 21.3 & 6 & 8 & 22.3 & 20.0 & 27.4 & 32.8 & 50.0 & 47.4 & 63.9 & 17.0 & 39.4 & 22.2 & 55.4 & 29.7 & 43 & 47.0 & 1.6 & 36.0 & 27.4 & 51.3 & 10.5 & 18.3 & 49.6 \\
\hline $\mathrm{Ce}$ & 73.8 & 48.3 & & 57.0 & 53.3 & 52.6 & 48.6 & 69.8 & 105.8 & 99.8 & 128.8 & 43.7 & 85.2 & 46.8 & 117.1 & 62.2 & & & 121.1 & 75.7 & 54.0 & 118.8 & 43.9 & 38.9 & 103.6 \\
\hline $\operatorname{Pr}$ & 9.31 & 6.35 & 12.60 & & 7.08 & 7.49 & 4.90 & 8.26 & 12.00 & 11.74 & 14.48 & 4.40 & 9.87 & 5.69 & 13.25 & 7.12 & 10.80 & 11.20 & 12.60 & 8.59 & 6.07 & 14.71 & 2.53 & 4.64 & 13.29 \\
\hline $\mathrm{Nd}$ & 37.7 & 27.5 & & 30.2 & 30.4 & 31. & 17.7 & 33.8 & 45.8 & 44.6 & 54.9 & 17.0 & 37.6 & 22.5 & 50 & 26.4 & 41.8 & 43 & 44.1 & 32.6 & 20.7 & & 9.5 & 17.6 & 55.0 \\
\hline $\mathrm{Sn}$ & & 5.87 & & & 6.12 & & & 6.07 & 6.95 & 7.3 & 8. & & 6. & 4.69 & 8 & 4.55 & 6. & 2 & 6.04 & 5.72 & 3.59 & 10.54 & 2.01 & 3.16 & 10.18 \\
\hline Eu & & & & & & & & & 1. & & & & & 1.12 & & & & & 1.97 & 1. & 1.2 & 1.24 & 0.62 & 0.98 & 2.36 \\
\hline $\mathrm{Gd}$ & 5. & 5. & & 7 & & & 1. & & 4. & & & & 5. & 4.5 & & 3. & & 6. & 4. & 4. & 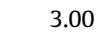 & 8.20 & 1.4 & 2. & 8.46 \\
\hline $\mathrm{Tb}$ & 0.86 & 0.73 & 0.87 & 1.3 & 0.9 & 0. & 0.2 & 0.9 & 0.62 & 0.79 & 0.92 & 0.44 & 0.7 & 0.8 & 0.81 & 0.5 & 0.6 & 1.0 & 0.57 & 0.6 & 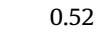 & 1.23 & 0.20 & 0.35 & 1.24 \\
\hline Dy & & & & & & & & & & & & & & 4.6 & & 2.7 & & 5.5 & 2.8 & 3.2 & & 6.05 & 0.95 & 1. & 6.19 \\
\hline Ho & 0.88 & 0.56 & 0.97 & 1.53 & 0.99 & 0.89 & 0.30 & 0.94 & 0.40 & 0.67 & 0.85 & 0.37 & 0.74 & 0.94 & 0.77 & 0.55 & 0.64 & 1.08 & 0.53 & 0.62 & 0.58 & 1.01 & 0.13 & 0.34 & 1.15 \\
\hline Er & & & & & & & & & & & & & & & & 1.6 & & 2.8 & & 1. & & 2.35 & 0.38 & & 2.95 \\
\hline $\mathrm{Tm}$ & 0.38 & 0.16 & 0.46 & 0.69 & 0.39 & 0.33 & 0.12 & 0.41 & 0.12 & 0.29 & 0.32 & 0.15 & 0.31 & 0.47 & 0.30 & 0.28 & 0.27 & 0.43 & 0.21 & 0.27 & 0.25 & 0.31 & 0.05 & 0.15 & 0.42 \\
\hline $\mathrm{Yb}$ & 2.36 & & 3.02 & & & & 0.7 & & 0.72 & 1.62 & & 0.90 & & 2.5 & & 1.6 & & 2.61 & 1.37 & 1.6 & 1.67 & 1.54 & 0.38 & 0.92 & 2.49 \\
\hline Lu & 0.34 & 0.13 & 0.45 & 0.6 & 0.3 & 0.24 & 0.12 & 0.33 & 0.11 & 0.24 & 0.25 & 0.14 & 0.28 & 0.4 & 0.25 & 0.27 & 0. & 0.38 & 0.21 & 0.25 & 0.27 & 0.21 & 0.05 & 0.14 & 0.34 \\
\hline $\mathrm{La} / \mathrm{Y}$ & 8.87 & 15.90 & 12.73 & 4.03 & 6.3 & 7.76 & 23.86 & 9.60 & 47.18 & 19.88 & 25.99 & 12.83 & 14.01 & 5.08 & 22.01 & 11.94 & 17.40 & 12.47 & 30.55 & 14.47 & 11.14 & 22.63 & 18.77 & 13.51 & 13.53 \\
\hline $\mathrm{Eu} / \mathrm{Eu}^{*}$ & 0.82 & 0.86 & 0.93 & 0.55 & 0.81 & 0.87 & 1.65 & 0.77 & 0.87 & 0.70 & 0.81 & 1.04 & 0.68 & 0.74 & 0.91 & 0.94 & 0.82 & 0.80 & 1.20 & 0.87 & 1.14 & 0.41 & 1.11 & 1.09 & 0.78 \\
\hline
\end{tabular}



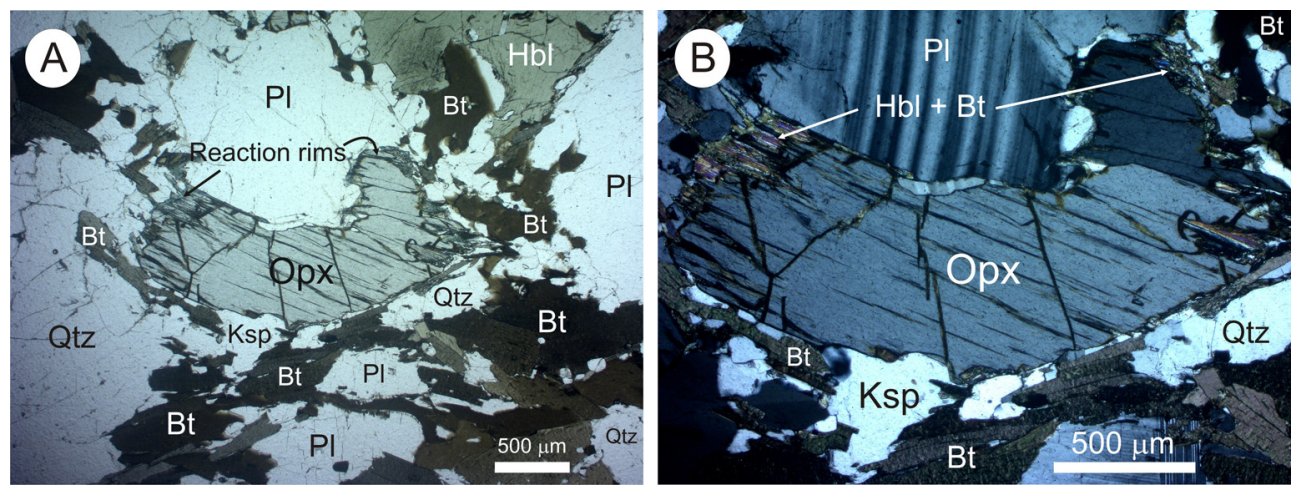

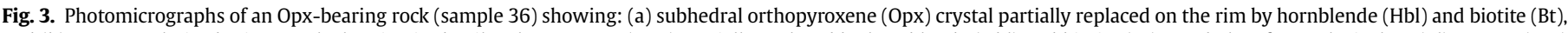

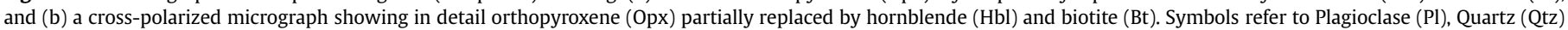
and K-feldspar (Ksp). See Fig. 2 for sample locality.

plagioclase $\left(\mathrm{An}_{35-88}\right)$, orthoclase, microcline, quartz, orthopyroxene and clinopyroxene (Nalini Jr., 1997). The accessory minerals are titanite, garnet, apatite (locally acicular), allanite, rutile, zircon, pyrrhotite, chalcopyrite, ilmenite, magnetite, pyrite and pentlandite.

The enclave-poor granite to tonalite rock group (GT) occurs mainly in the central and southeastern portions of the study area (Fig. 2). The studied rocks are light gray, medium to coarse-grained, and consist in average of quartz ( $\sim 45 \%$ ), plagioclase (up to $25 \%$ ), $\mathrm{K}$ feldspar (microcline and ortoclase, up to $20 \%$ ), biotite ( $\sim 7 \%$ ), and hornblende $(\sim 3 \%)$. Most biotite crystals are primary, but occasionally it is a product of hornblende breakdown. Quartz shows undulose extinction, subgrains or minor recrystallized grains. Feldspars sometimes show polygonal, straight and long boundaries. Zircon, allanite, titanite and occasionally garnet are common accessory minerals. Although many parts of GT plutons are free of solid-state foliation and show preserved igneous features (Fig. 4b), this rock group also includes highly deformed portions. It is common to find euhedral feldspar grains with straight boundaries (Fig. 4c), suggesting an igneous origin, as well as quartz grains with weak undulose extinction and straight boundaries that form dihedral contact at $120^{\circ}$. The GT rock unit shows variable amounts of melanocratic to mesocratic enclaves. Extensive bodies free of mafic enclaves also occur. The lack of enclaves may be explained by one or more of the following reasons: i) exposures of plutons cut in different erosional levels (like in eroded batholiths composed of incestuous plutons; Pitcher, 1997); ii) upper crustal level, allochthonous plutons emplaced far from magma mixing zones; iii) plutons or part of them composed of more evolved melts formed from fractional crystallization; iv) plutons or part of them composed by more differentiated melts formed by partial melting of other granitic plutons of the arc itself and/or from basement sources of adequate composition.

\section{Geochemistry of the G1 Supersuite}

The analyzed samples include 8 tonalites/enderbites (ETG, GT and Opx-bearing groups), 11 granodiorites (ETG and GT groups), 4 monzogranites (GT group), 1 gabbro (Opx-bearing group), and 1 diorite (Opx-bearing group) (Table 2).

The analyzed rocks forming the G1 Supersuite in the study area vary from diorite to alkali-granite, with granodiorite and tonalite representing by far the most representative rocks of the supersuite (Fig. 5). The composition of the intermediate and acid rocks of the G1 Supersuite is strongly variable, they are both magnesian and ferroan (Fig. 6a), metaluminous and peraluminous and from calcic to alkali-calcic (Fig. 6b and c). The Opx-bearing rocks are essentially magnesian, while the ETG and GT rocks range from magnesian to ferroan compositions (Fig. 6a). The ETG rocks are calcic, whilst the GT and Opx-bearing rocks cover from calcic to alkali-calcic compositions (Fig. 6b). The Opx-bearing rocks are dominantly metaluminous, with one exception (sample L222), which is peraluminous $(\mathrm{A} / \mathrm{CNK}=1.20)$, whilst the GT and ETG rocks plot into the transition field between metaluminous and peraluminous rocks (Fig. 6c). All together, the analyzed rocks show similarity to an expanded calc-alkaline series (Fig. 6d).

When compiled the geochemical dataset of the G1 granitoids, the diagrams show that the great majority of the rocks are magnesian ( $\sim 80 \%)$, metaluminous to slightly peraluminous ( $\sim 84 \%$ ) and between calcic and calc-alkalic ( $~ 83 \%$ ) (Fig. 6a-c). The gabbroic rocks plot mostly on the calc-alkaline field (Fig. 6d).

The Opx-bearing rocks have $\mathrm{SiO}_{2}$ content ranging from 56.44 wt.\% to 66.61 wt.\%, whilst for the ETG and GT rocks the $\mathrm{SiO}_{2}$ content varies from 63.98 wt.\% to 72.80 wt.\%, and from 62.69 wt.\% to 76.18 wt.\%, respectively (Fig. 7, and Table 2). The $\mathrm{K}_{2} \mathrm{O}$ content is between 0.86 wt.\% and 4.39 wt.\% for the Opx-bearing rocks, between 1.01 wt.\% and 3.63 wt.\% for the ETG rocks, and between 2.58 wt.\% and 6.25 wt.\% for the GT rocks (Table 2). The highest $\mathrm{CaO}$ content of 6.82 wt.\% was observed in the Opx-bearing rock group (sample L243), while the lowest value of 1.15 wt.\% (sample L197) was obtained in the GT rock group. A slightly positive correlation between $\mathrm{SiO}_{2}$ and $\mathrm{K}_{2} \mathrm{O}$ is displayed by all rock groups (Fig. 7a). A clear negative correlation between $\mathrm{CaO}$ and $\mathrm{SiO}_{2}$, as well as between $\mathrm{V}$ and $\mathrm{SiO}_{2}$ could be observed (Fig. $7 \mathrm{~b}$ and $\mathrm{c}$ ). On the other hand, a slightly negative correlation between $\mathrm{Ni}$ and $\mathrm{SiO}_{2}$, and $\mathrm{Sr}$ and $\mathrm{SiO}_{2}$ could be observed for all rock groups (Fig. $7 \mathrm{c}, \mathrm{d}$ and f). The highest V (168 ppm), and $\mathrm{Ni}(31.2 \mathrm{ppm})$ contents were obtained in the rocks of the Opx-bearing group, samples L243 and L222, respectively (Table 2). The highest $\mathrm{Sr}$ (641.8 ppm), and the lowest $\mathrm{Sr}$ (159 ppm) contents were obtained in the rocks of the Opx-bearing group (sample L222), and of the GT group (sample L197), respectively (Table 2). No clear correlation could be observed between $\mathrm{SiO}_{2}$ and $\mathrm{Rb}$, although a general positive correlation could be inferred (Fig. 7e).

When compared with literature data on the Rio Doce arc, the geochemical dataset shows that the Opx-bearing rocks record the greatest chemical variability, with $\mathrm{SiO}_{2}$ ranging from 53.8 wt.\% to 74.6 wt.\%, maficity (Fe $+\mathrm{Mg}$ ) from 0.02 to 0.24 (Fig. 6c) and $\mathrm{K}_{2} \mathrm{O}$ from 0.9 wt.\% to 7.3 wt.\% (Fig. 7a). A significant percentage ( $40 \%$ ) of the Opx-bearing rocks plots in the field of alkali-calcic rocks (Fig. 6b). They show Mg\# ranging from 0.22 to 0.58 , and are particularly enriched in $\mathrm{V}$ and $\mathrm{Ni}$ with respect to the other 

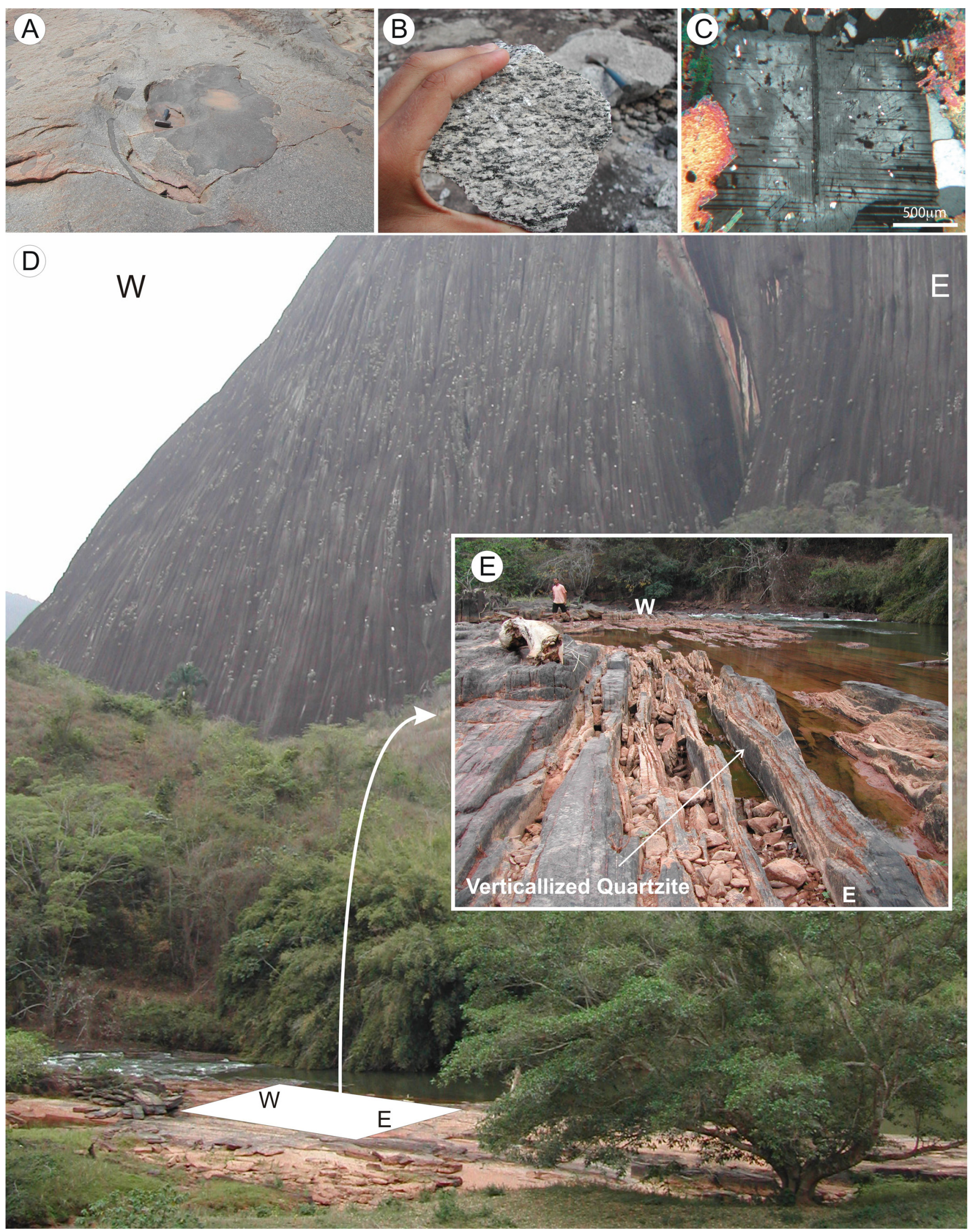

Fig. 4. Field pictures and microphotographs of the G1 Supersuite. a) Metric-scale diorite enclave hosted in granodiorite; b) Granite sample with biotite defining the foliation; c) Granite sample with well preserved euhedral feldspar grain; d) Massive granite pluton with (e) verticallized quartzite exposed close to its boundary with the country rock. 


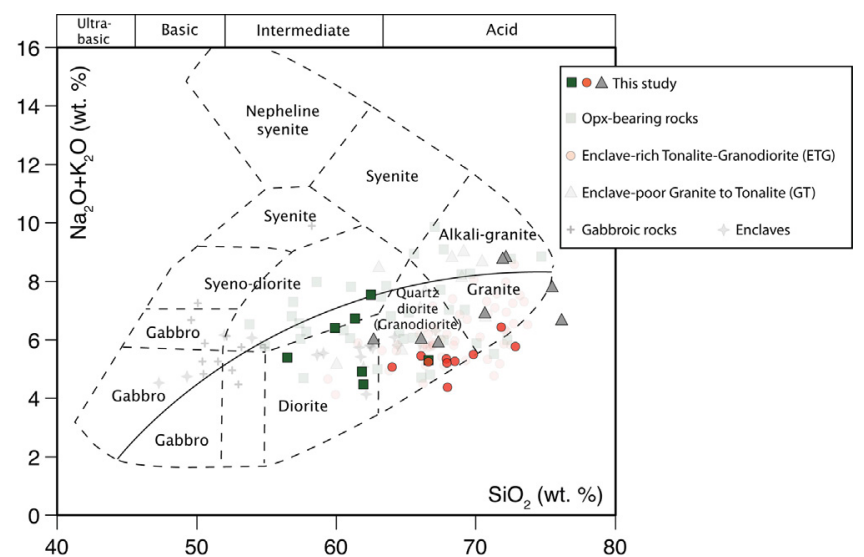

Fig. 5. Plot of $\mathrm{Na}_{2} \mathrm{O}+\mathrm{K}_{2} \mathrm{O}$ versus $\mathrm{SiO}_{2}$ (wt. \%) content showing the great variability of the rocks forming the G1 Supersuite, which range mostly from diorites to alkaligranites. Note that the compositions of the enclaves, which are hosted in the ETG rocks, and gabbroic rocks are also plotted (after Wilson, 1989). Symbols: square - Opxbearing rocks; circle - ETG rocks; triangle - GT rocks. Samples from this study are highlighted. See the text for further discussion. described lithologies (Fig. 7c and d). The GT and ETG rocks have $\mathrm{SiO}_{2}$ content varying from 59.4 wt.\% to 76.2 wt.\%. At similar $\mathrm{SiO}_{2}$ contents, GT rocks have higher $\mathrm{K}_{2} \mathrm{O}$ and lower $\mathrm{CaO}$ than ETG rocks (Fig. 7a and b), thus the former have higher MALI $\left(\mathrm{Na}_{2} \mathrm{O}+\mathrm{K}_{2} \mathrm{O}-\mathrm{CaO}\right)$, with $\sim 28 \%$ and $\sim 39 \%$ of samples plotting in the calc-alkalic and alkali-calcic fields, respectively (Fig. 6b). The GT and ETG rocks show Mg\# values that range between 0.05 and 0.55 , which are similar to values found for Opx-bearing rocks.

The GT, ETG and Opx-bearing rocks display similar REE patterns characterized by enrichment in LREE over HREE with $(\mathrm{La} / \mathrm{Yb})_{\mathrm{N}}$ ratios ranging mainly between $\sim 4$ and $\sim 47$. Fig. $8 \mathrm{a}-\mathrm{c}$ shows the fractionation patterns for the three groups of rocks. The GT rocks are slightly enriched in LREE than the other groups. The Opxbearing rocks display both positive and negative Eu anomalies (Fig. 8a), while GT and ETG rocks show mostly negative anomalies (Fig. $8 \mathrm{~b}$ and c) with average $\mathrm{Eu} / \mathrm{Eu}^{*}$ of 0.93 and 0.83 , respectively.

\section{U-Pb geochronology}

Previous $\mathrm{U}-\mathrm{Pb}$ zircon geochronological studies in the area between the towns of Governador Valadares and Ipanema (Fig. 2) have been limited to a small number of samples: one from the G5 Supersuite (Petitgirard et al., 2009), one from the G2 Supersuite
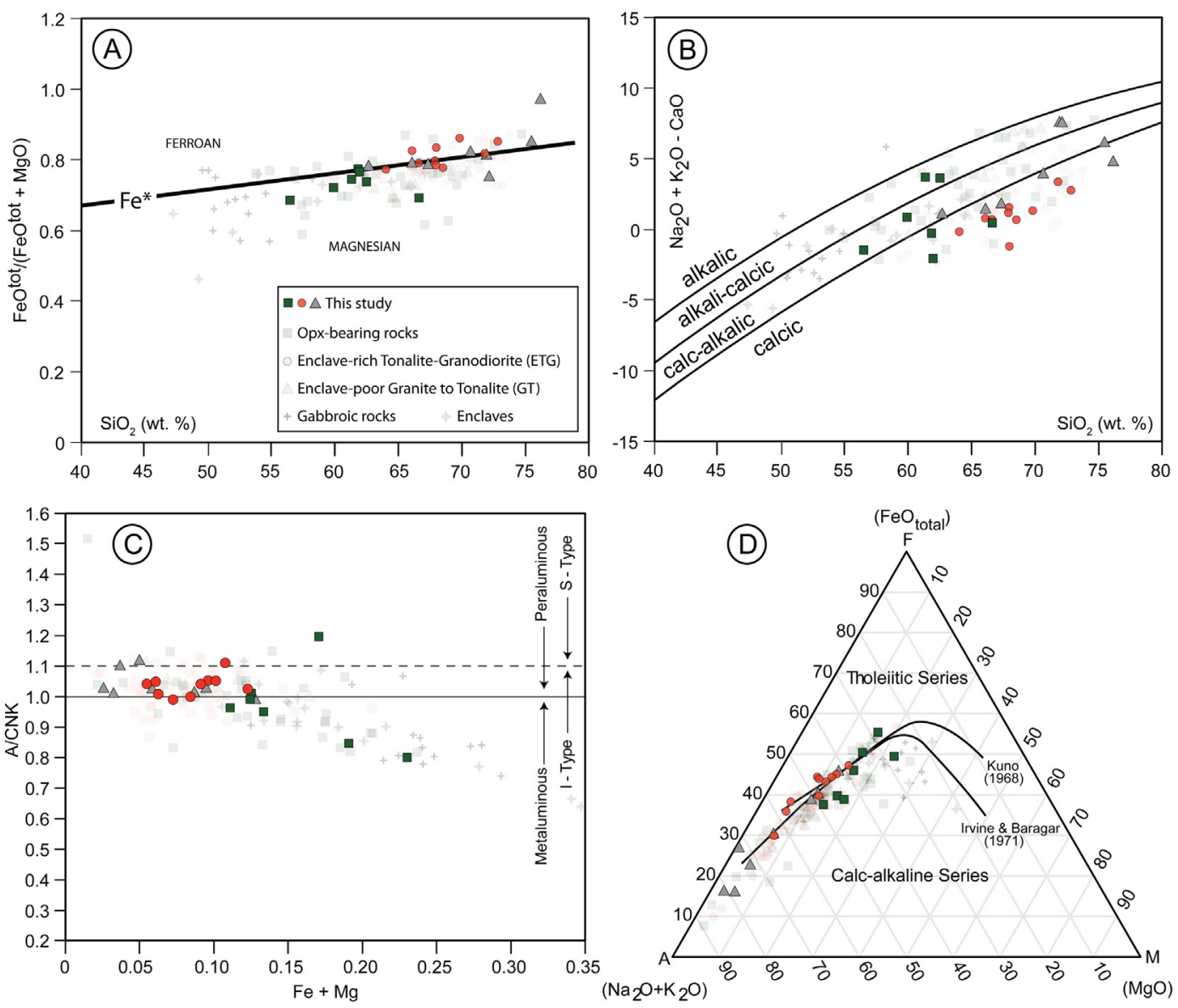

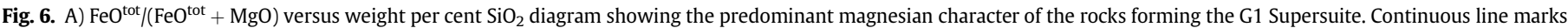

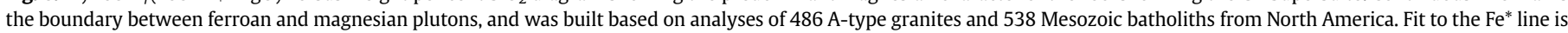

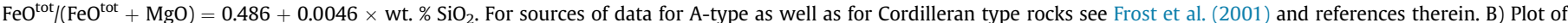

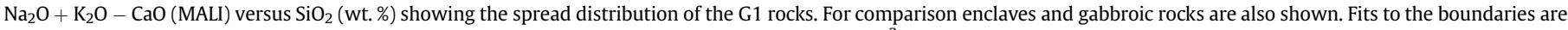

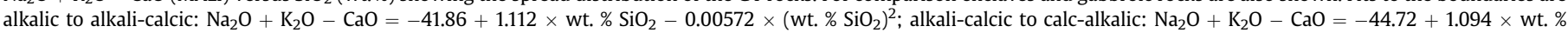

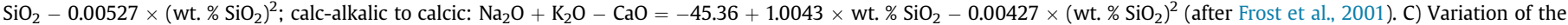

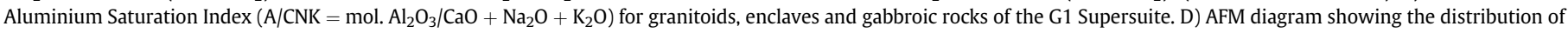
the G1 rocks, which is similar to a typical calc-alkaline series (after Rickwood, 1989). Symbols as in Fig. 5. See the text for further discussion. 


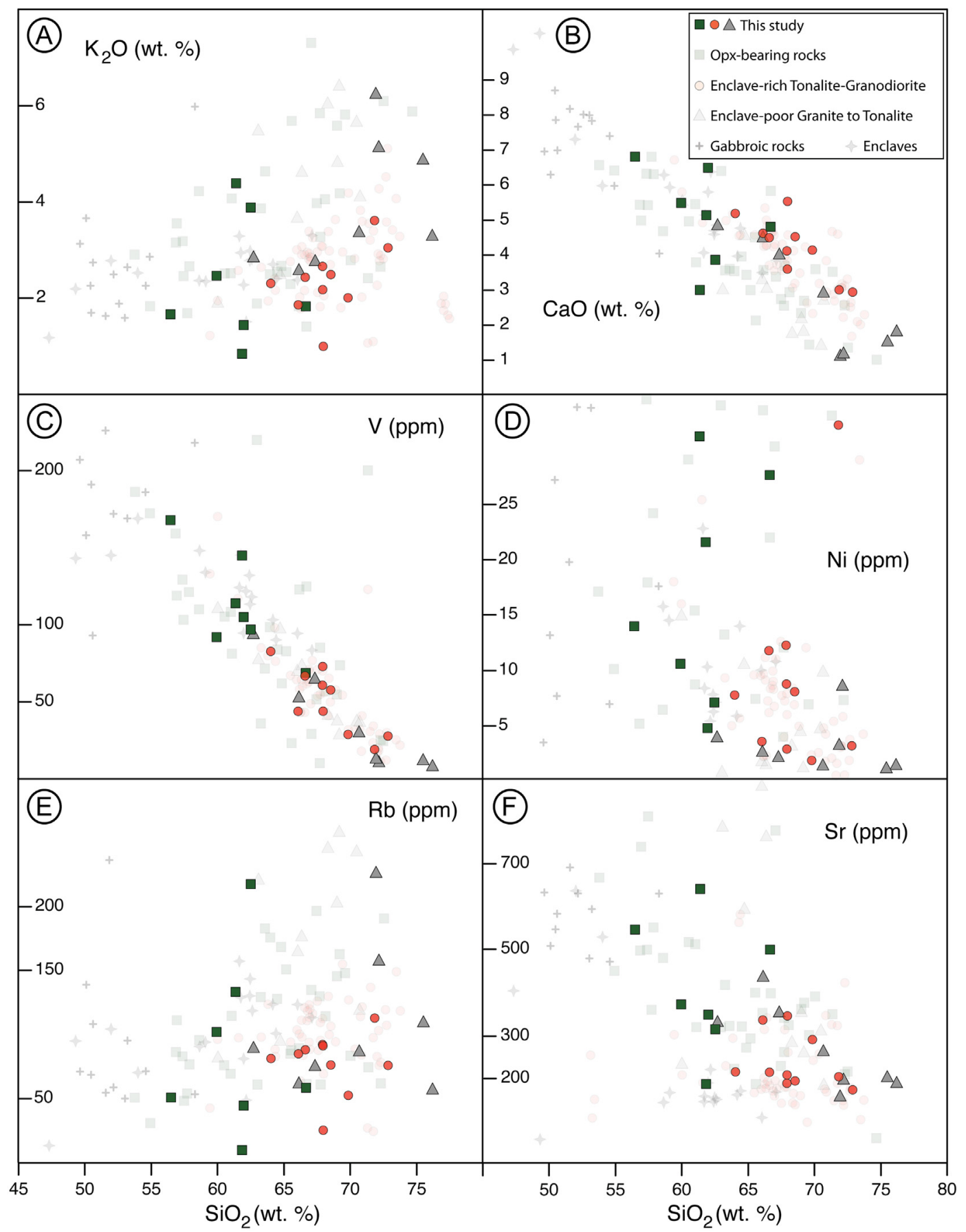

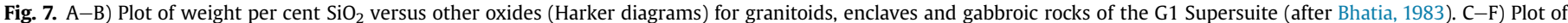
weight per cent $\mathrm{SiO}_{2}$ versus other trace elements. Symbols as in Fig. 5. See the text for further discussion.

(Nalini Jr. 1997), two from the G1 Supersuite (Nalini Jr. 1997; Petitgirard et al., 2009), and two from the meta-volcanics of the Rio Doce Group (Vieira, 2007) (Fig. 2). In this study we have focused on the age of the surrounding basement which may have contributed to the G1 magmatism. We analyzed five rock samples: three samples from the basement rocks, as well as one from the Opxbearing rocks and one from the mafic enclaves within the ETG group.

\subsection{Basement rocks (samples 247, 17A and 17B)}

Sample 247 (UTM 807430/7842740) was collected in the southwestern region of the study area from an enderbite that belong to the Juiz de Fora Complex. The enderbite is greenish fineto medium-grained and shows an isotropic aspect (Fig. 9a and b). Samples 17A and 17B (UTM 266028/7857896) were collected close to each other from a fine- to medium-grained banded orthogneiss that belongs to the Pocrane complex, in the central eastern region of the study area (Fig. 2). The orthogneiss is characterized by alternating leucocratic and melanocratic bands ranging from $\mathrm{cm}$ - to metric wide (Fig. 9c). The leucocratic band consists predominantly of quartz and feldspar, whilst the melanocratic band is made up of hornblende and biotite, which define the rock foliation. The accessory assemblage is composed of zircon, apatite, titanite, epidote and occasionally garnet. 

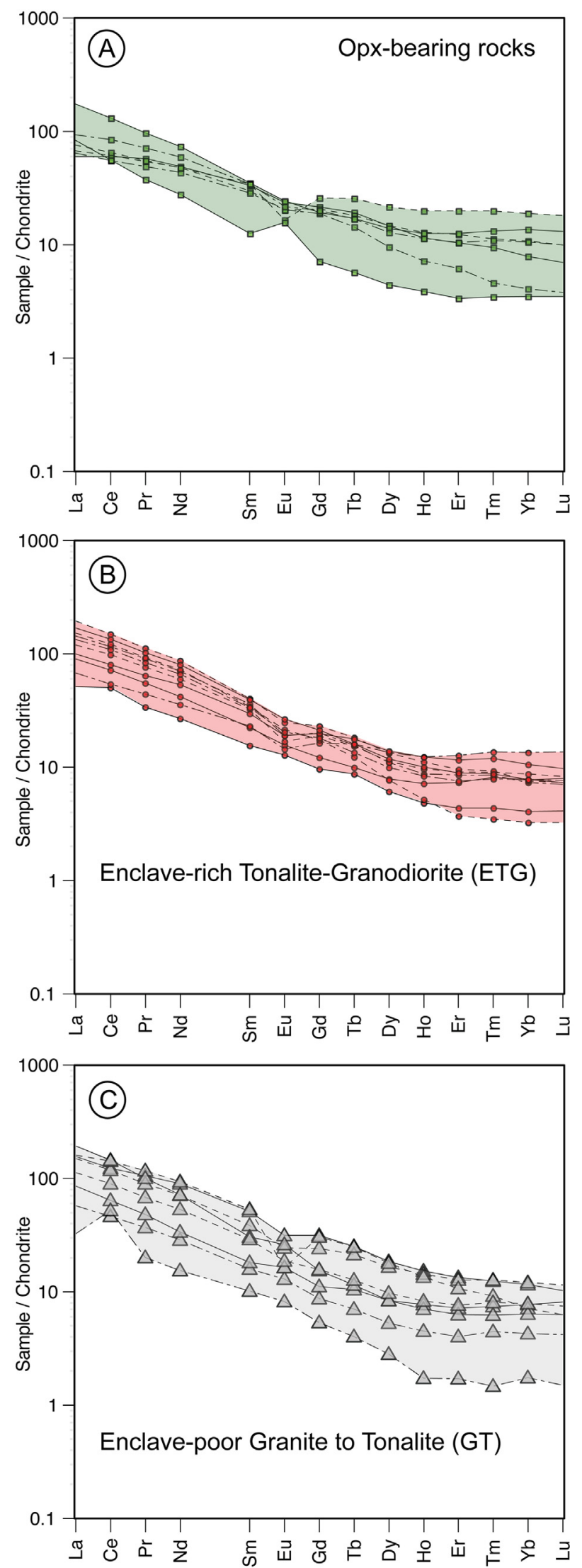

Fig. 8. Rare Earth Elements diagrams normalized by Chondrite, according to values of Nakamura (1974). The diagrams show the pattern of the three rock groups (a) Opxbearing rocks; (b) ETG rocks and (c) GT rocks, which are similar to arc-related magmatic rocks. Shadow area delimits the REE concentration for data from this study. See the text for further discussion.
The zircon grains extracted from these samples (samples 247, $17 \mathrm{~A}$ and $17 \mathrm{~B}$ ) are very similar and comprise long-prismatic and large elongate grains (up to $400 \mu \mathrm{m}$ ), with length/width ratios predominantly of 3:1, although higher ratios up to $4: 1$ are observed. They are light-gray and most zircon grains display magmatic oscillatory zoning with no inherited cores on CL images (Fig. 10a). However, some of the grains show roundish or embayment cores with visible truncation with the surrounding oscillatory rims. Several attempts to date these cores have failed and no coherent age data could be obtained. Most grains have Th/U ratios ranging from 0.20 to 0.76 , which are indicative of a magmatic origin. Sometimes, these grains show corroded boundaries, however no metamorphic overgrowth was observed.

Twenty spots obtained in the same number of zircon grains of the sample 247 yielded upper intercept at $2116 \pm 13 \mathrm{Ma}$ and lower intercept at $638 \pm 38$ Ma (MSWD = 2.1) (Fig. 11a). The upper intercept age is interpreted as the best approximation of the magmatic crystallization age of this sample. Fifty spots obtained from cores and rims of 25 zircon crystals for the sample $17 \mathrm{~A}$ yielded upper intercept at $2102 \pm 8 \mathrm{Ma}$ and lower intercept at $420 \pm 120 \mathrm{Ma}$ (MSWD = 3.9) (Fig. 11b). The upper intercept is interpreted to be the crystallization age of this sample. Forty two spots obtained in the same number of zircon grains for the sample 17B plot along a Pb-loss Discordia with intercept ages of $2102 \pm 5 \mathrm{Ma}$ and $332 \pm 130 \mathrm{Ma}(\mathrm{MSWD}=1.13$ ). The upper intercept age is similar (within error) of a concordia age of $2099 \pm 9 \mathrm{Ma}(\mathrm{MSWD}=1.7)$ given by eight concordant $(<1 \%$ disc.) spots (Fig. 11c). We interpret the concordia age as the crystallization age of this sample. Assuming these results as the best estimate for orthogneisses and enderbite crystallization ages for the basement of the Rio Doce arc, they are in accordance to data available in the literature (Machado et al., 1996; Noce et al., 2007; Heilbron et al., 2010).

\subsection{Granitoids and enclaves (samples 242 and 3, respectively)}

Sample 242 (UTM 807645/7835314) was collected in the southwestern extremity of the study area (Fig. 2). This sample is a gray fine- to medium-grained tonalite and consists of hornblende, biotite, plagioclase, quartz and microcline. Accessory mineral assemblage and secondary minerals are made up of titanite, zircon, allanite, garnet, ilmenite, magnetite, pyrrhotite, \pm chalcopyrite, \pm pyrite, clinozoisite, muscovite and chlorite. The microstructural aspect of this sample is very similar to that earlier described for the enderbite (sample 247) of the Juiz de Fora complex, except that hypersthene was not observed on thin sections for the tonalite. Locally, mm- to cm-wide quartz veins are observed (Fig. 9d). Zircon grains extracted from this sample consist of short-prismatic, elongate or even zircon grains with rounded boundaries. They have length/width ratios mainly of $2.5: 1$, although higher values up to 3:1 were obtained. The axes of zircon grains range from $130 \mu \mathrm{m}$ to $300 \mu \mathrm{m}$. Most grains are dark-gray and display magmatic oscillatory zoning with inherited cores on CL images (Fig. 10b). Attempts to obtain ages from these cores were unsuccessful due to the high level of discordance, however apparent ages are suggestive of a heritance from basement rocks of $2100 \mathrm{Ma}$. Although rounded boundary is a typical feature, no metamorphic overgrowth was observed. Nineteen spots from 19 grains of the sample 242 yielded a mean ${ }^{206} \mathrm{~Pb} /{ }^{238} \mathrm{U}$ age of $597 \pm 4 \mathrm{Ma}$ (MSWD = 1.3) (Fig. 11d). This age is interpreted as the best approximation of the crystallization age of this sample.

Sample 3 (UTM 239888/7880586) was collected from an abandoned quarry in the northeastern portion of the study area, in the vicinity of Conselheiro Pena (Fig. 2). The outcrop consists of a granodiorite with an enormous volume of enclaves. This 

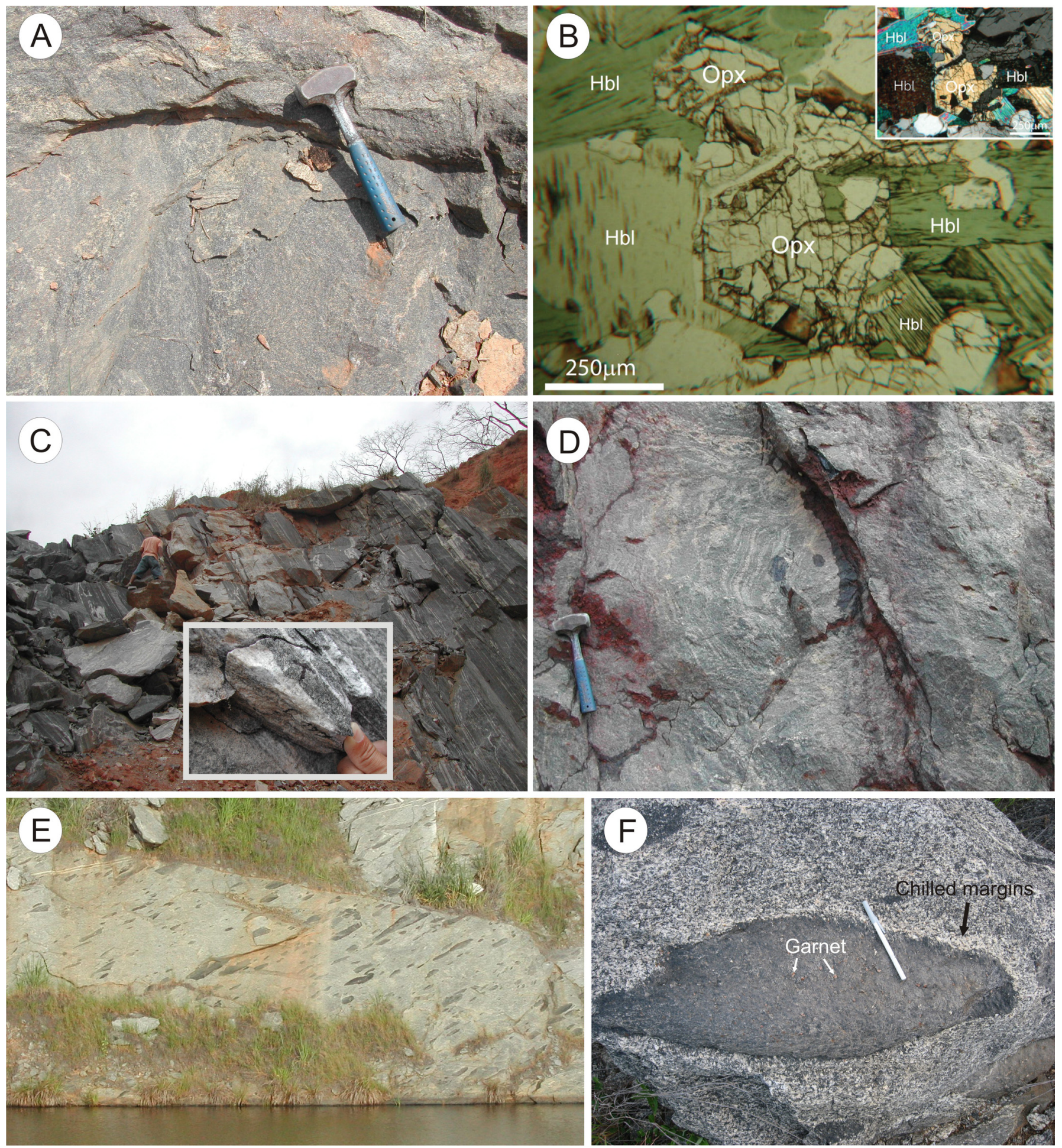

Fig. 9. A) Macroscopic view of the enderbite sample from the Juiz de Fora complex showing its roughly banded structure - sample 247. B) Microscopic distribution of the main mineral assemblage showing hornblende ( $\mathrm{Hbl}$ ) crystals as likely product of retrograde metamorphism of orthopyroxene (Opx) (transmitted light; polarized light image in the upper right corner). C) Macroscopic aspect of a typical banded orthogneiss from the Pocrane complex, detail of the banding in the middle of the photo. D) Macroscopic aspect of the Tonalite from the Opx-bearing rock of the G1 Supersuite - sample 242. E) General view of the outcrop close to Conselheiro Pena town - sample 3. F) Detailed image of an enclave showing chilled margins, in the right side and milimetric garnet crystals - sample 3 (see Fig. 2 for samples locality).

granodiorite yielded magmatic crystallization ages of $579 \pm 8 \mathrm{Ma}$ (Gonçalves, 2009), while a granodiorite nearby yielded magmatic crystallization age of $594 \pm 6$ Ma (Fig. 2; Nalini Jr., 1997). The enclaves range in composition from tonalite/diorite to gabbro (Fig. 5); particularly in the sampled place it is a diorite. They have external rounded shape or are strongly elongated and foliated parallel to the regional pervasive foliation of country rocks (Fig. 9e and f). Zircon grains of this sample comprise two distinct populations. The first is made up of short-prismatic, elongate or even zircon grains with rounded boundaries, similar to the previous sample (sample 242). 


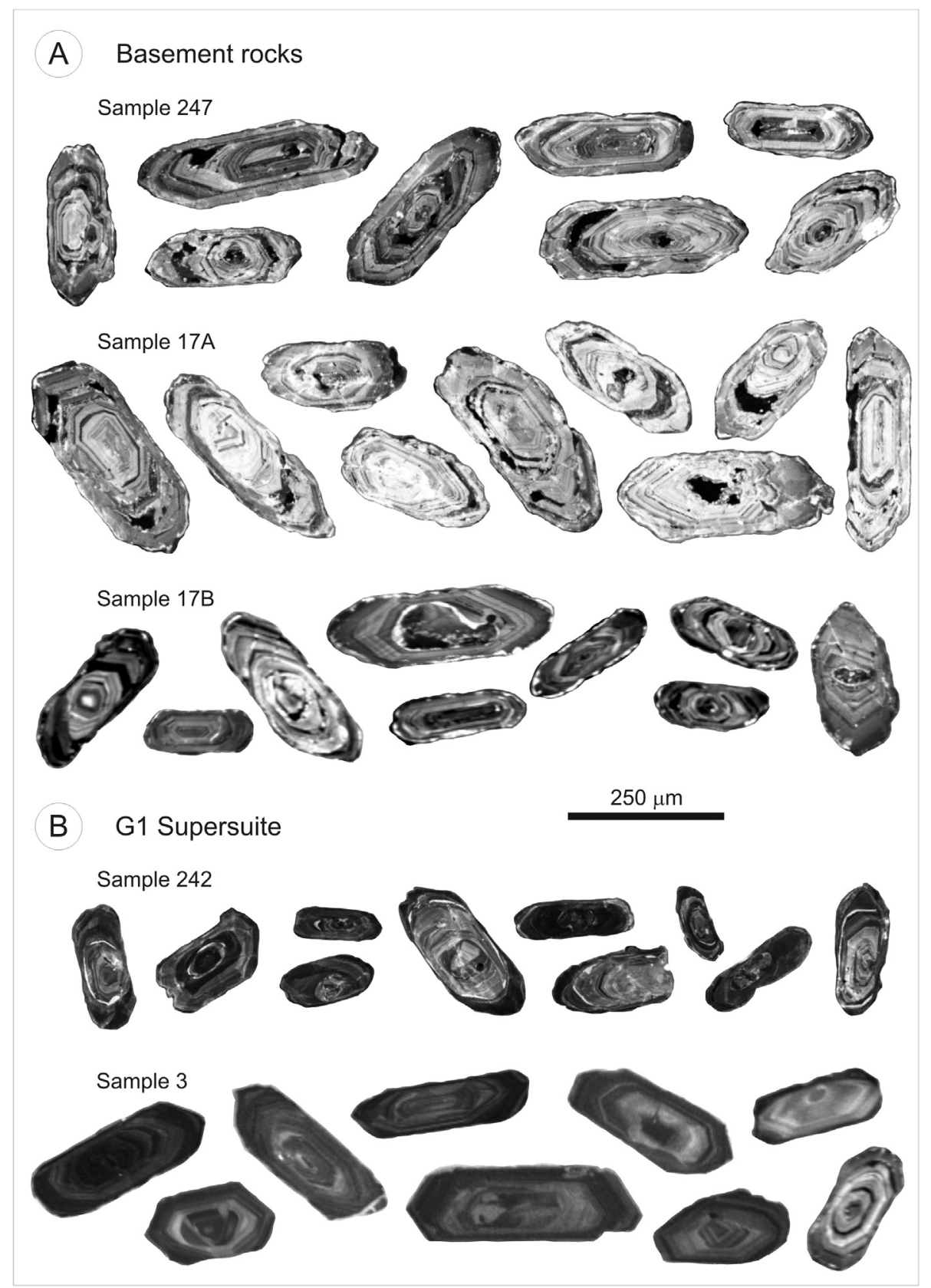

Fig. 10. CL images showing the external characteristics and internal structures of zircon crystals extracted from: A) basement rocks (sample 247 - Juiz de Fora complex, and samples 17A and 17B - Pocrane complex). B) G1 Supersuite (sample 242 - tonalite from the Opx-bearing rocks, and sample 3 - quartz-dioritic enclave hosted in granodiorite from the enclave-rich tonalite-granodiorite group).

They have length/width ratios mainly of 2.5:1, although higher values up to 3:1 were obtained. The second population consists of long-prismatic and large elongate grains, which are similar to zircon grains from basement rocks (samples 247, 17A and 17B). Most grains are dark-gray and display magmatic oscillatory zoning with inherited cores on CL images (Fig. 10b). Although rounded boundary is a typical feature, no metamorphic overgrowth was observed. Twenty seven concordant to near-concordant $(<2 \%$ of discordance) spot analyses from the same number of zircon grains yielded a mean ${ }^{206} \mathrm{~Pb} /{ }^{238} \mathrm{U}$ age of $581 \pm 3 \mathrm{Ma}(\mathrm{MSWD}=0.21$ ) for the sample 3 (Fig. 11e). We interpreted the $581 \pm 3$ Ma mean age as the crystallization age of this sample. Seven spots obtained in 7 zircon crystals for the same sample yielded a concordia age of $2117 \pm 9 \mathrm{Ma}$
$($ MSWD $=1.8)$ (Fig. 11f) and it is interpreted as inherited zircon grains from the continental Rhyacian basement.

\section{Discussion}

The G1 Supersuite, as exposed between the towns of Governador Valadares and Ipanema in eastern Minas Gerais, consists of three distinct associations of grantitic rocks: the Opx-bearing, enclave rich and enclave poor rock groups. The Opx-bearing group is composed of predominantly green-grayish tonalitic rocks, mostly poor in enclaves. The enclave-rich rocks (ETG group) consist of light to dark gray tonalites and granodiorites, crowded of centimetric to metric-sized melanocratic to mesocratic enclaves. 

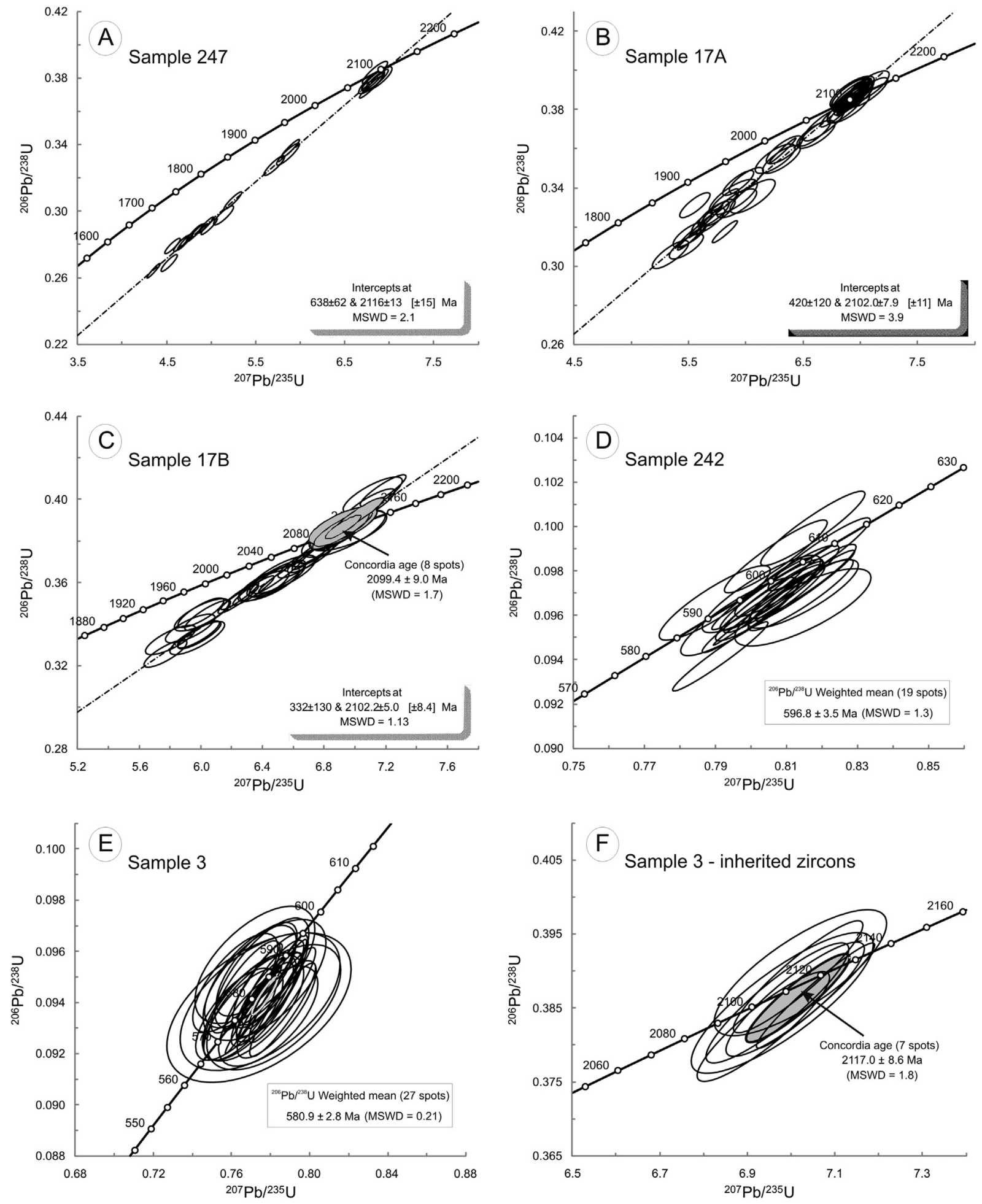

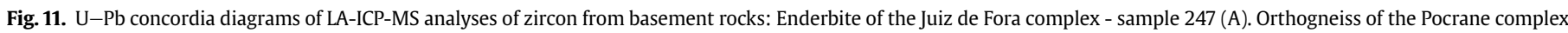

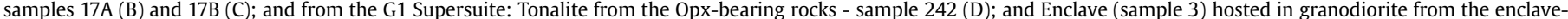
rich tonalite-granodiorite group and (E) with magmatic age of inherited zircon grains from the Rhyacian basement (F) (see Fig. 2 for sample locality).

The enclave-poor rocks (GT group) are made up of light gray granites to tonalites, with rare occurrence of enclaves.

The geochemical signature of 7 samples of the Opx-bearing group revealed that it is composed of magnesian (Figs. 5 and 6a), calcic to alkali-calcic (Fig. 6b), predominantly metaluminous tonalites (Fig. 6c). Similar to a calc-alkaline series (Fig. 6d), the rocks of this group are less evolved, in terms of the $\mathrm{SiO}_{2}$ content, than the components of ETG and GT groups (Fig. 7). The Opx-bearing rocks have $\mathrm{SiO}_{2}$ content in average of $61.50 \mathrm{wt} . \%$, whilst the ETG and GT have $\mathrm{SiO}_{2}$ content in average of 68.32 wt.\% and 70.31 wt.\%, respectively (Table 2). The geochemical characteristics of the rocks belonging to the ETG group (10 samples) and GT group (8 samples) 
largely overlap. These rocks are magnesian to ferroan (Fig. 6a), predominantly calcic (Fig. 6b) and ranging from metaluminous to peraluminous terms (Fig. 6c).

The geochemical data presented here show that these granitoids are mostly magnesian, calc-alkalic to alkali-calcic, metaluminous to slightly peraluminous, and have a typical calc-alkaline trend, thus compositionally similar to other Cordilleran-type granitoids worldwide (e.g., Frost et al., 2001; Frost and Frost, 2008, and references therein).

Even though the study area does not cover the whole arc, it is clear that the analyzed samples cover the entire geochemical diversity shown by the Rio Doce arc rocks (Figs. 5-7). In this sense, 150 samples from the literature (from published and unpublished data, see Supplementary Data Item 1 for reference details) are now grouped according to the three rock groups here defined, based on field, petrographic and mainly the geochemical criteria. Therefore the initial 25 analyzed samples translate to: 43 geochemical analyses of rocks belonging to the Opx-bearing group, 70 analyses of rocks of the ETG group, 20 analyses of rocks of the GT rock group, as well as 22 analyses of enclaves and 14 analyses of gabbroic rocks.

Our new zircon $\mathrm{U}-\mathrm{Pb}$ data belonging to the Opx-bearing group (sample 242), an enclave within the ETG group (sample 3), and the Rhyacian basement rocks (samples 247 and 17A and 17B) are in good agreement with previous data available to the pre-collisional G1 magmatism (630-580 Ma), as well as to the basement ( $2100 \mathrm{Ma}$ ) of the Rio Doce arc (Nalini Jr. et al., 2000; Silva et al., 2002, 2005; Pedrosa-Soares et al., 2011; Figueiredo, 2009; Gonçalves, 2009; Novo et al., 2010; Petitgirard et al., 2009; Mondou et al., 2012; Novo, 2013; Tedeschi, 2013).

The three main groups range from acidic to intermediate igneous rocks (Table 3 ), and display similar $\mathrm{U}-\mathrm{Pb}$ zircon crystallization ages ( $c$. 580-600 Ma). The available data only allow us to discuss possible petrogenetic processes under a regional perspective, as the studied rock groups do not represent individual plutons but composite batholithic masses (Fig. 2). Determining the unequivocal origin and source rocks of the Rio Doce arc may not be possible, due to the large range in composition and age of the rocks (630-580 Ma) forming this arc (Figueiredo and Campos-Neto, 1993; Nalini Jr. et al., 2005; Pedrosa-Soares and WiedemannLeonardos, 2000; De Campos et al., 2004; Martins et al., 2004; Gonçalves et al., 2010; Novo et al., 2010; Pedrosa-Soares et al., 2011).

Regionally, the granitic rocks forming plutons of the G1 Supersuite range in composition from diorite to alkali-granite, and their Opx-bearing equivalents, being predominant tonalite to granodiorite rocks (Fig. 5). The individualized rock groups follow the positive correlation for $\mathrm{K}$ and $\mathrm{Rb}$, and the negative tendency for $\mathrm{Ca}, \mathrm{V}, \mathrm{Ni}$ and $\mathrm{Sr}$ against $\mathrm{SiO}_{2}$ content. Indeed, the occurrence of diorites and gabbros suggest the involvement of mantle-derived magmas in the genesis of the G1 Supersuite (Nalini Jr. et al., 2000; Pedrosa-Soares et al., 2011). However, the large petrographic and chemical variability characterizing the G1 granitic rocks, together with their large emplacement age range, suggest that different processes are likely to have contributed to shape the chemical composition of the supersuite, with the relative importance of these processes varying substantially for distinct plutons and batholiths.

Among possible petrologic processes (e.g., Pitcher, 1997; Annen and Sparks, 2002; Chappel, 2004; Annen et al., 2006; Clemens et al., 2011; Clemens and Stevens, 2012; Farina et al., 2012), we focus on the following main possibilities: i) fractional crystallization of mantle-derived magmas of gabbroic composition with assimilation of host rock as these magmas rose through the crust and emplaced, the so-called MASH process (melting, assimilation, storage and homogenization of deep crustal hot zones near the crust-mantle boundary); ii) mixing between crust- and mantle-derived magmas, with mafic enclaves representing evidence to support this process; iii) partial melting of plutonic sources with intermediate to acidic composition, relatively rich in biotite and hornblende.

It is worth noting that these three models have a strong implication on the mechanisms of formation of continental crust. In fact, the amount of juvenile magmas involved in the three scenarios is drastically different. According to the first process the G1 Supersuite would represent a major event of net crustal growth, while following the last hypothesis the amount of juvenile crust formed is only minor and the supersuite would comprise recycling outcomes from older continental crust. The second hypothesis stands between these end-members and represents a combination of the MASH and crustal melting processes. Actually, these processes have been proposed to occur simultaneously, with heat and $\mathrm{H}_{2} \mathrm{O}$ released from the crystallizing primary magmas acting as the trigger for the crustal melting (Annen and Sparks, 2002).

\subsection{Evolution of mantle-derived magmas}

The efficacy of MASH depends on the efficient co-functioning of fractional crystallization, assimilation and magma mixing. Although this model may be involved at some extent in the generation of the G1 Supersuite, there are three lines of evidence arguing against MASH to explain the chemical diversity of the G1 Supersuite.

Firstly, the Sr and Nd isotopic composition available for the G1 Supersuite is typically crustal in signature (Nalini Jr., 1997, Martins et al., 2004; Pedrosa-Soares et al., 2011), although this may be accepted for continental magmatic arcs. In particular, Novo et al. (2010) analyzed the $\mathrm{Nd}$ isotopic signature (epsilon $\mathrm{Nd}=-10$; $\mathrm{T}_{\mathrm{DM}}$ model age $\sim 2 \mathrm{Ga}$ ) of two $600 \mathrm{Ma}$ Opx-bearing rocks of intermediate composition $\left(\mathrm{SiO}_{2}=54-57 \%\right)$ and relatively low-K

Table 3

Main features of the rocks forming the G1 Supersuite.

\begin{tabular}{|c|c|c|c|c|}
\hline \multirow[t]{2}{*}{ Group } & \multicolumn{2}{|l|}{ Mineralogy } & \multirow[t]{2}{*}{ Geochemistry } & \multirow[t]{2}{*}{ Field observations } \\
\hline & Main minerals & Accessory minerals & & \\
\hline Opx-bearing rocks & $\begin{array}{l}\text { orthopyroxene, clinopyroxene, } \\
\text { biotite, hornblende, plagioclase, } \\
\text { quartz and microcline }\end{array}$ & $\begin{array}{l}\text { Titanite, zircon, allanite, } \\
\text { garnet, pyrrhotite, } \\
\text { chalcopyrite, pyrite and } \\
\text { pentlandite }\end{array}$ & $\begin{array}{l}\text { Magnesian, calc-alkalic to } \\
\text { alkali-calcic and metaluminous }\end{array}$ & $\begin{array}{l}\text { Predominantly greenish, fine-to } \\
\text { medium-grained charnockites to } \\
\text { enderbites }\end{array}$ \\
\hline $\begin{array}{l}\text { Enclave-rich } \\
\text { Tonalite and } \\
\text { Granodiorite }\end{array}$ & $\begin{array}{l}\text { biotite, hornblende, plagioclase, } \\
\text { quartz, orthoclase and microcline }\end{array}$ & $\begin{array}{l}\text { Garnet, titanite, allanite, } \\
\text { apatite, rutile, ilmenite, } \\
\text { magnetite, pyrrhotite } \\
\text { and chalcopyrite }\end{array}$ & $\begin{array}{l}\text { Metaluminous to slightly } \\
\text { peraluminous, calc-alkaline, } \\
\text { intermediate-silicic plutonic } \\
\text { rocks }\end{array}$ & $\begin{array}{l}\text { Light to dark gray, medium to } \\
\text { coarse-grained Granodiorites and } \\
\text { Tonalites, rich in cm- to m- long } \\
\text { melanocratic enclaves }\end{array}$ \\
\hline $\begin{array}{l}\text { Enclave-poor } \\
\text { Granite to Tonalite }\end{array}$ & $\begin{array}{l}\text { biotite, hornblende, orthoclase, } \\
\text { microcline, quartz and plagioclase }\end{array}$ & $\begin{array}{l}\text { Zircon, allanite, titanite } \\
\text { and garnet }\end{array}$ & & $\begin{array}{l}\text { Light gray, medium to coarse-grained } \\
\text { Granites to Tonalites, mostly poor of } \\
\text { enclaves }\end{array}$ \\
\hline
\end{tabular}


contents $\left(\mathrm{K}_{2} \mathrm{O} / \mathrm{Na}_{2} \mathrm{O}+\mathrm{CaO}=0.16-1.3\right)$, concluding for an important involvement of the Rhyacian granulitic basement in the origin of the Divino Suite. However, this suite also includes abundant gabbroic and dioritic rocks, pointing to significant mantle contribution, and an expanded high-K calc-alkaline signature and correlations in Harker diagrams suggesting fractional crystallization (Novo et al., 2010).

$\mathrm{Sr}$ and $\mathrm{Nd}$ isotopic composition of eight samples from four tonalite-granodiorite samples of the G1 Supersuite exposed in the northern part of the arc have variable negative $\mathrm{Nd}$ values $(-5.6$ to -12.9$)$ but relatively constant $\left({ }^{87} \mathrm{Sr} /{ }^{86} \mathrm{Sr}\right)_{\mathrm{i}}$ values $(0.710-0.709)$ (Martins et al., 2004). Sr and Nd data from five ETG samples from the Galiléia batholith (granodiorites, tonalites and enclaves sampled near the town of Conselheiro Pena) also record negative Nd values $(-8.3$ to -9.3$)$ and relatively similar $\left({ }^{87} \mathrm{Sr} /{ }^{86} \mathrm{Sr}\right)_{\mathrm{i}}$ values (0.712-0.713) (Nalini Jr., 1997). Although assimilation of crustal rocks by the primary magmas may drive the composition of mantle-derived magmas toward higher ${ }^{87} \mathrm{Sr} /{ }^{86} \mathrm{Sr}$ and lower ${ }^{143} \mathrm{Nd} /{ }^{144} \mathrm{Nd}$, the crustal signature described for the reported samples requires large volumes of assimilated crust. This is in contrast with the existence of thermal limitations on the incorporations of whole-rock material into basaltic magmas (Glazner, 2007). In fact, the energy consumed in this processes results in considerable cooling, crystallization and formation of hybrid magmas that are so highly crystallized to become immobile and incapable of undergoing further magmatic evolution (Clemens and Stevens, 2012). On the other hand, our samples were collected from tonalites and granodiorites rich in gabbroic to dioritic enclaves, which suggest contribution from mantelic magma.

Secondly, assuming that plagioclase and orthopyroxene are the main minerals to fractionate from the gabbroic primary magma, gabbros involved in fractional crystallization should be 3 or 4 times more voluminous than the co-genetic granitoids with production of significant volumes of cumulatic gabbros (Fig. 12). In fact, there is no record of such cumulatic rocks in the G1 Supersuite. However, we cannot exclude that these rocks have not been found due to the lack of detailed studies on individual plutons, or that they were delaminated, due to their high density, in the collisional to postcollisional stages of evolution of the Araçuaí orogen.

Finally, plagioclase $(\mathrm{Pl})$ and orthopyroxene $(\mathrm{Opx})$ fractionation do not account for the great chemical diversity shown by the G1
Supersuite (Fig. 12a and b). Assuming that the chemical composition of the primary magma of the G1 Supersuite could be that of a gabbroic rock (sample T1 from an outcrop in the southern portion of the arc; Novo, 2009; Novo et al., 2010), it would be necessary to fractionate large proportions of $\mathrm{Pl}$ and Opx or even $\mathrm{Pl}$ and olivine (Ol) to reach the end-acid members (Fig. 12a and b). Indeed, using $\mathrm{CaO}$ and maficity as fractionation markers, crystallization larger than $\sim 20 \% \mathrm{Pl}$ and $\sim 20 \%$ Opx would not fit the G1 Supersuite trend for both markers (Fig. 12a and b). This proportion would be even lower considering the synchronous $\mathrm{Pl}$ and $\mathrm{Ol}$ crystallization, $\sim 5 \%$ and $\sim 4 \%$, respectively (Figs. 12a and b).

Fractional crystallization has been postulated as a first-order mechanism controlling the magmatic evolution of the G1 Galiléia batholith (Nalini Jr. et al., 2005). Although such process may play an important role for the evolution of single plutons (Nalini Jr. et al., 2005; Novo et al., 2010), there is no evidence, in a regional scale, to consider fractional crystallization as a first-order mechanism to explain the chemical diversity shown by the G1 Supersuite.

\subsection{Magma mixing and mingling}

The occurrence of mafic bodies such as synplutonic dykes, pillows and enclaves in intermediate to felsic host rocks is commonly considered a strong evidence supporting hybridization between highly felsic melts from the continental crust and mantle-derived magmas to produce granodiorite and tonalite in many different tectonic settings (e.g., Pitcher, 1991). The widespread occurrence of mafic enclaves within most G1 plutons, and the occurrence of gabbroic plutons in the rock record of the G1 Supersuite indicate the involvement of mantle-derived magmas in the genesis of the supersuite. However, the real conundrum is to establish how and to what extent these mantle-derived magmas influenced the composition of the volumetrically dominant granitoid magma in the G1 Supersuite.

The importance of this process may vary substantially from pluton to pluton (e.g., Nalini Jr. et al., 2005, Pedrosa-Soares et al., 2011). Therefore, an estimation of the role of mantle-derived magmas in the origin of the G1 Supersuite would imply detailed studies on selected areas and would strongly rely on isotopic data that are not available.
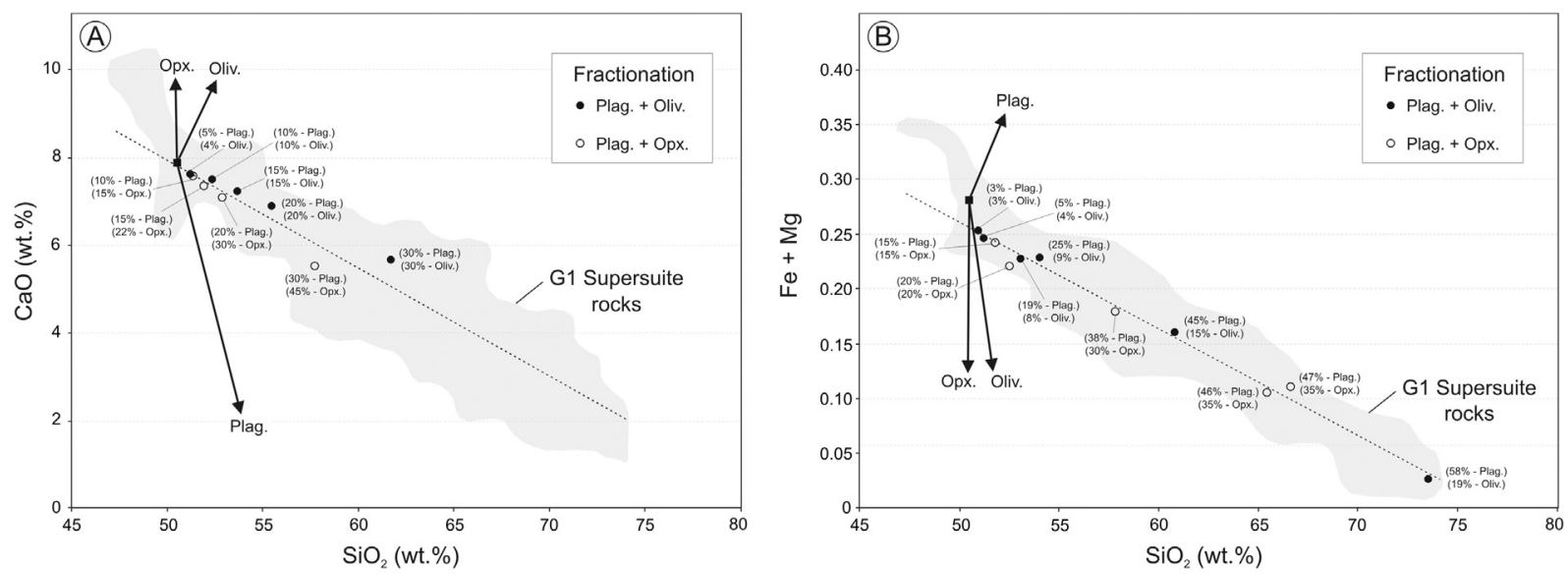

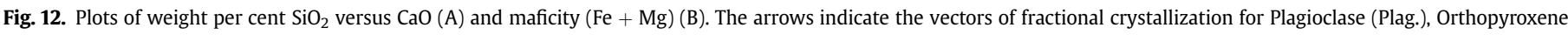

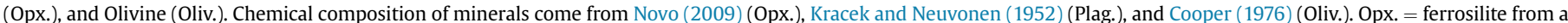

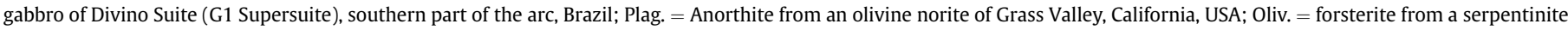

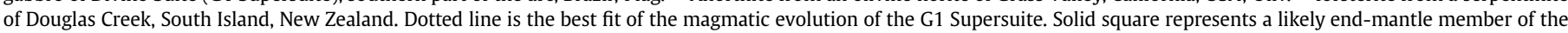

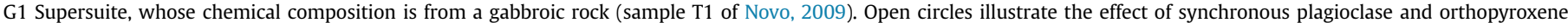

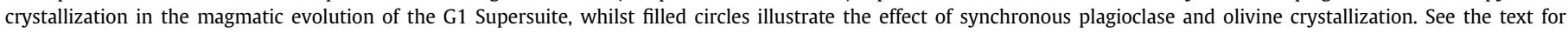
additional explanation. 


\subsection{Recycling the basement rocks}

The $\mathrm{G} 1$ rocks intrude the Rhyacian orthogneisses of the Juiz de Fora and Pocrane complexes. The ca. 2.1 Ga U-Pb ages from this study, as well as published ages (Machado et al., 1996; Silva et al., 2011; Noce et al., 2007; Heilbron et al., 2010) clearly pin point the Pocrane and Juiz de Fora complexes as part of the Rhyacian component of the basement of the Araçuaí orogen. The granitoids of the G1 Supersuite, as well as some mafic enclaves hosted within them, contain large amounts of ca. 2.1 Ga inherited zircon grains that are possibly related to the Juiz de Fora and Pocrane rocks (Table 1; Fig. 11f). Thus, $\mathrm{U}-\mathrm{Pb}$ crystallization and inherited ages presented here and in previous studies indicate a close association between G1 granitic rocks and the Rhyacian orthogneisses that make up the continental basement of the Rio Doce arc.

The $\mathrm{U}-\mathrm{Pb}$ information complements the isotope data suggesting that rocks of the Rhyacian basement contributed for the genesis of G1 granitoids. The occurrence of mafic enclaves within tonaliteto-granite plutons, as well as the occurrence of gabbroic plutons indicates the initial involvement of mantle-derived magmas. However, it is worth noting that the $\mathrm{SiO}_{2}$ and maficity $(\mathrm{Fe}+\mathrm{Mg}$ ) content of ETG and GT largely overlaps, suggesting that the difference between the two groups is unlikely to be produced by different degrees of interaction with a mantle-derived endmember.

The rocks forming the ETG and GT groups show overall chemical characteristics of I-type granitoids (e.g., Farina et al., 2012): a decrease in ASI with increasing maficity (Fig. 6c) as well as a negative correlation between $\mathrm{CaO}$ content and $\mathrm{SiO}_{2}$ (Fig. 7b). These characteristics have been recently interpreted by Clemens et al. (2011) as resulting from biotite and hornblende partial melting of immature sediments with andesitic/dacitic composition and entrainment of a peritectic assemblage mostly constituted of pyroxene and plagioclase. The main difference between the ETG and GT groups is their alkali content, with GT rocks being significantly more $\mathrm{K}_{2} \mathrm{O}$-rich than ETG rocks at similar $\mathrm{SiO}_{2}$. Partial melting experiments on metapelites and metagreywackes show how the $\mathrm{K}$ and Na content in granitic magmas reflect the stoichiometry of the melting reactions and the chemistry of the source (Farina et al., 2012). In particular, the $\mathrm{K}: \mathrm{Na}$ of partial melts is related to the variability of the biotite/plagioclase ratio in the melting reaction, (biotite is the main K-bearing phase) as well as plagioclase composition (plagioclase is the main Na-bearing phase) in the source.

We suggest that the difference between the $\mathrm{K}_{2} \mathrm{O}$ content of ETG and GT may reflect: 1 ) the occurrence of two different fertile protoliths in the crust during the genesis of the magmatic arc; 2) different heating cycle between two areas broadly characterized by the same sources. This latter hypothesis is based on the evidence that fluid-absent melting of biotite typically begins at temperatures around $830^{\circ} \mathrm{C}$ (at $0.5 \mathrm{GPa}$; Stevens et al., 1997) while temperatures as high as $900{ }^{\circ} \mathrm{C}$ are required for hornblende melting (Skjerlie and Patiño Douce, 1995). According to the first hypothesis, partial melting of a biotite-hornblende source with intermediate composition was involved in the magmatism of the ETG rocks, while GT rocks show the contribution of mostly biotite fluid-absent melting of a more mature source with little contribution from hornblende melting. Alternatively, the heating cycle below ETG rocks allow temperature as high as $900{ }^{\circ} \mathrm{C}$ to be achieved and maintained enhancing coupled biotite and hornblende melting, while lower temperatures were reached in the crust below GT rocks. This second interpretation is in agreement with the large amount of mafic enclaves in the ETG rocks, while GT rocks are poor or free in mafic enclaves. In fact, the mafic enclaves can witness underplating of mantle-derived magmas producing higher and more persistent temperature anomalies.

The composition of GT rocks is much more variable than that of ETG granitoids with some of the GT rocks showing enrichment in $\mathrm{K}$ and $\mathrm{Rb}$ and others displaying extremely high $\mathrm{Sr}$ content (Fig. 7a, e and 7f). This second-order variability within the individual identified lithotypes suggests that different petrogenetic processes have contributed to shape the composition of the G1 rocks. Accordingly, although detailed calculations of crystal fractionation and assimilation-fractional crystallization processes for the G1 Supersuite is out of the scope of this work, we present a general hypothesis for the petrogenesis of the Rio Doce magmatic arc. In this approximation partial melting processes are favored, although we believe that an unequivocal origin for the magmas responsible for the evolution and development of the Rio Doce arc is a challengeable work, still to be done.

\subsection{The charnockites forming the G1 supersuite}

The intermediate to felsic (charnockitic) Opx-bearing plutonic rocks of the G1 Supersuite exhibit strongly variable chemical composition ranging from magnesian to ferroan and from calcic to alkalic (Fig. 6a and b). However, most of the charnockites are magnesian, calc-alkalic to alkali-calcic and metaluminous, thus compositionally similar to Cordilleran batholiths (Frost and Frost, 2008). The overall arc-like major and trace element compositions of the Opx-bearing rocks of the G1 Supersuite suggest that these charnockites represent the roots of the Rio Doce magmatic arc. The capacity of granitic magmas to dissolve and react with orthopyroxene during ascent, causing early, anhydrous, ferromagnesian minerals to be supplanted by hornblende and biotite, is related to the increase in $\mathrm{a}_{\mathrm{H} 2 \mathrm{O}}$ and $\mathrm{a}_{\mathrm{K} 2 \mathrm{O}}$ taking place in the magma during crystallization. This observation lead Frost et al. (1989) to conclude that if pyroxenes are to survive in a granitoid, charnockites must represent cumulates that formed early in the crystallization of a pluton, and were isolated from later, more hydrous portions of the batholith. However, the composition of the Opx-rocks of the G1 Supersuite is significantly scattered, with poor or absent positive linear correlations within the elements hosted in the early crystallizing phases (i.e., orthopyroxene and plagioclase) favoring other processes rather than fractional crystallization for the genesis of these rocks. The crustal $\mathrm{Sr}$ and Nd isotopic signature displayed by the charnockites of the G1 Supersuite led us to suggest, following Young et al. (1997), that high-temperature partial melting of dry and largely restitic, granulitic crustal sources may have been contributed for its genesis.

\section{Conclusions}

Field and petrographic observations, geochemistry and geochronology of one of the best exposed segments of the Rio Doce arc, combined with geochemical/isotopic data from the literature, led us to the following conclusions:

1. The Ediacaran continental Rio Doce magmatic arc of the Araçuaí orogen comprises a great diversity of rocks. In the study area, the rocks range from diorites to alkali granites with tonalite and granodiorite representing by far the most representative rocks of the arc. Three rock groups could be distinguished, namely: Opx-bearing rocks, enclave-rich tonalite-granodiorite (ETG), and enclave-poor granite to tonalite (GT).

2. The Rio Doce magmatic arc consists mostly of granitoids chemically similar to a series of magnesian, calc-alkalic to alkalicalcic, metaluminous to slightly peraluminous, which are 
compositionally similar to Cordilleran-type granitoids worldwide.

3. U-Pb zircon ages reveal that, in the study area, the rocks forming the Rio Doce arc crystallized between 597 and $581 \mathrm{Ma}$, with ages roughly around $2.1 \mathrm{Ga}$ obtained from inherited cores of zircon proving that a Rhyacian continental crust may be involved in the $\mathrm{G} 1$ rocks production. These results are in good agreement with the current literature about the Araçuaí orogen, particularly regarding the early development stages responsible for the building of its magmatic arc, the continental Rio Doce magmatic arc.

4. Key chemical and mineralogical features suggest that different igneous processes may be involved in the development of the Rio Doce arc. These processes are: i) fractional crystallization of mantle-derived magmas of gabbroic composition with assimilation of host rock as these magmas rose through the crust and emplaced; ii) mixing between crust- and mantle-derived magmas, with mafic enclaves representing evidence to support this process; iii) partial melting of plutonic sources with intermediate to acidic composition, relatively rich in biotite and hornblende. In the light of the present knowledge it is impossible to evaluate the real contribution of each one of the mentioned process. Most likely, playing different roles in distinct portions of the crust they compete during the formation of the Rio Doce arc.

\section{Acknowledgments}

This work was supported by Coordenação de Aperfeiçoamento de Pessoal de Nível Superior (CAPES), providing a Ph.D. fellowship to L. Gonçalves, and by Conselho Nacional de Desenvolvimento Científico e Tecnológico (CNPq, Brazil), grants to C. Lana (\# 402852/ 2012-5), F. Alkmim, and A. C. Pedrosa-Soares. The authors are grateful to Reinhardt Fuck for the careful editorial handling, Massimo Matteini and an anonymous reviewer, whose criticism led to significant improvement of the manuscript. We also want to thank Cristiane Castro Gonçalves for providing helpful comments on the manuscript.

\section{Appendix A. Supplementary data}

Supplementary data related to this article can be found at http:// dx.doi.org/10.1016/j.jsames.2014.02.008.

\section{Appendix I}

\section{LA-ICP-MS}

The laser ablation-ICP-MS method (LA-ICPMS) has been developed to yield reliable $\mathrm{U}-\mathrm{Pb}$ ages on zircon on a routine basis at the Departamento de Geologia, Universidade Federal de Ouro Preto, Brazil. The analyses were performed using an Agilent 7700 Q-ICPMS and a $213 \mathrm{~nm}$ New Wave laser. Operating conditions were optimized to provide maximum sensitivity for the high masses $\left({ }^{207} \mathrm{~Pb}\right.$ and $\left.{ }^{238} \mathrm{U}\right)$ while inhibiting oxide formation (ThO+/ $\mathrm{Th}+<1.0 \%$ ). The standard and unknown zircons were ablated in small volume (tear-drop shape) sample cell, with an insert that holds one 25 -mm-diameter sample mount and a 7-mm-diameter standard mount. Acquisitions consisted of a $20 \mathrm{~s}$ measurement of the gas blank, followed by $40 \mathrm{~s}$ measurement of $\mathrm{U}$, Th and $\mathrm{Pb}$ signals during ablation, and $30 \mathrm{~s}$ washout. Samples, standards and sample holders were acid-washed before being analysed to remove possible surface $\mathrm{Pb}$ contamination. Laser ablations were performed at $40 \mu \mathrm{m}$ spot size, $\sim 6-8 \mathrm{~J} / \mathrm{cm}^{2}$ fluence and $10 \mathrm{~Hz}$ repetition rate. Ablations occurred in a He carrier gas, and the resulting aerosol was mixed with Ar prior to introduction into the ICP-MS via $4 \mathrm{~mm}$ Tygontubing (pre-cleaned with $1 \%$ ultra-pure nitric acid). Integration times were $15 \mathrm{~ms}$ for ${ }^{206} \mathrm{~Pb} ; 40 \mathrm{~ms}$ for ${ }^{207} \mathrm{~Pb}$ and $10 \mathrm{~ms}$ for ${ }^{208} \mathrm{~Pb} ;{ }^{204} \mathrm{~Pb}+\mathrm{Hg} ;{ }^{232} \mathrm{Th},{ }^{238} \mathrm{U}$.

The relevant isotopic ratios $\left({ }^{207} \mathrm{~Pb} /{ }^{206} \mathrm{~Pb},{ }^{208} \mathrm{~Pb} /{ }^{206} \mathrm{~Pb}\right.$, ${ }^{208} \mathrm{~Pb} /{ }^{232} \mathrm{Th},{ }^{206} \mathrm{~Pb} /{ }^{238} \mathrm{U}$ and ${ }^{207} \mathrm{~Pb} /{ }^{235} \mathrm{U}$, where ${ }^{235} \mathrm{U}$ was calculated from ${ }^{238} \mathrm{U}$ counts via the natural abundance ratio ${ }^{235} \mathrm{U}={ }^{238} \mathrm{U} /$ 137.88) have been calculated using the data reduction software Glitter (van Achterbergh et al., 2001). Individual isotopic ratios were displayed in time-resolved mode. For our laser system, isotopic ratios generated during the first $5 \mathrm{~s}$ of each analysis were discarded. The integration window for the remainder of each analysis was chosen so as to maximize concordance and to exclude signal segments that were related to zones of $\mathrm{Pb}$ loss (e.g., fractures), high common $\mathrm{Pb}$ (as recognized by ${ }^{204} \mathrm{~Pb}+\mathrm{Hg}$ counts markedly higher than the high background caused by ${ }^{204} \mathrm{Hg}$ contamination) or $\mathrm{Pb}$ inheritance. Instrumental drift was corrected against the zircon standard using linear interpolative fits. Calibrations were based on six or more analyses of the standard (6-8 analyses of unknowns bracketed between 2 and 3 analyses of standards). ${ }^{204} \mathrm{~Pb}$-based common $\mathrm{Pb}$ corrections were not applied.

Two secondary standards were used during runs: Plešovice zircon (337 \pm 1 Ma; Sláma et al., 2008) and M127 zircon (524 $\pm 1 \mathrm{Ma}$; Klötzli et al., 2009). Twenty four analyses of Plešovice zircon std gave a Concordia age of $338 \pm 2 \mathrm{Ma}$ (mean ${ }^{207} \mathrm{~Pb} /{ }^{206} \mathrm{~Pb}$ age $=344 \pm 12 ;$ mean ${ }^{206} \mathrm{~Pb} /{ }^{238} \mathrm{U}$ age $=338 \pm 2 ;$ mean ${ }^{207} \mathrm{~Pb} /{ }^{235} \mathrm{U}$ age $=338 \pm 2 \mathrm{Ma}$ ). Nineteen analyses of the M127 zircon std gave a Concordia age of $522 \pm 3 \mathrm{Ma}\left(\right.$ mean ${ }^{207} \mathrm{~Pb} /{ }^{206} \mathrm{~Pb}$ age $=522 \pm 13$ mean ${ }^{206} \mathrm{~Pb} /{ }^{238} \mathrm{U}$ age $=523 \pm 3 ;$ mean ${ }^{207} \mathrm{~Pb} /{ }^{235} \mathrm{U}$ age $522 \pm 3 \mathrm{Ma}$ ). See Supplementary Data for detailed information about the individual analyses and "within run" ages obtained for these zircon standards.

\section{References}

Alkmim, F.F, Marshak, S. Pedrosa-Soares, A.C. Peres, G.G. Cruz, S.C.P. Whittington, A., 2006. Kinematic evolution of the Araçuaí-West Congo orogen in Brazil and Africa: nutcracker tectonics during the neoproterozoic assembly of Gondwana. Precamb. Res. 149, 43-64.

Annen, C., Sparks, R.S.J., 2002. Effects of repetitive emplacement of basaltic intrusions on thermal evolution and melt generation in the crust. Earth Planet. Sci. Lett. 203, 937-955.

Annen, C., Blundy, J.D., Sparks, R.S.J., 2006. The genesis of intermediate and silicic magmas in deep crustal hot zones. J. Petrol. 47, 505-539.

Barbosa, A. L. de M., Grossi Sad, J.H., Torres, N., Melo, M.T.V., 1964. Geologia das quadrículas de Barra do Cuieté e Conselheiro Pena, Minas Gerais. DNPM/GEOSOL, Belo Horizonte, p. 285.

Barbosa, A.L. de M., Grossi Sad, J.H., Torres, N., Melo, M.T.V., 1966. Descrição do mapa geológico preliminar do Médio do Rio Doce. Geologia da Região do Médio do Rio Doce (Excursão 2: Aos pegmatitos de Governador Valadares) 2. Sociedade Brasileira de Geologia, Núcleo Rio de Janeiro, Rio de Janeiro, pp. $1-10$

Bhatia, M.R., 1983. Plate tectonics and geochemical composition of sandstones. J. Geology 91, 611-627.

Brito Neves, B.B., Campos Neto, M.C., Fuck, R., 1999. From Rodinia to Western Gondwana: an approach to the Brasiliano/Pan-African cycle and orogenic collage. Episodes 22, 155-199.

Chappel, B., 2004. Causes of variation in granite suitesThe Ishihara Symposium: granites and associated Metallogenesis. Geosci. Can., 27-34. http://www.ga. gov.au/image_cache/GA3677.pdf.

Clemens, J.D., Stevens, G., 2012. What controls chemical variation in granitic magmas? Lithos 134-135, 317-329.

Clemens, J.D., Stevens, G., Farina, F., 2011. The enigmatic sources of I-type granites: the peritectic connexion. Lithos 126, 174-181.

Cooper, A.F., 1976. Concentrically zoned ultramafic pods from the Haast schist zone, South Island, New Zealand. N. Z. J. Geology Geophys. 19, 603-623.

Cordani, U.G., D’Agrella-Filho, M.S., Brito-Neves, B.B., Trindade, R.I.F., 2003. Tearing up Rodinia: the Neoproterozoic paleogeography of South American cratonic fragments. Terra Nova 15, 350-359.

Costa, A.G., 1998. The granulite-facies rocks of the northern segment of the Ribeira Belt, eastern Minas Gerais, SE Brazil. Gondwana Res. 1 (3-4), 367-372.

De Campos, C., Mendes, J., Ludka, I., de Medeiros, S., de Moura, J., Wallfass, C., 2004 A review of the Brasiliano magmatism in southern Espírito Santo, Brazil, with emphasis on post-collisional magmatism. In: Weinberg, R., Trouw, R., Fuck, R., 
Hackspacher, P. (Eds.), The 750-550 Ma Brasiliano Event of South America. J. Virtual Explor. ISSN: 1441-8142 17. Electronic Edition Paper 1.

Duarte, B.P., Figueiredo, M.C.H., Campos Neto, M., Heilbron, M., 1997. Geochemistry of the Granulite Facies Orthogneisses of Juiz de Fora Complex, Central Segment of Ribeira Belt, Southeastern Brazil. Rev. Bras. Geociências 27, 67-82.

Duarte, B.P., Heilbron, M., Campos Neto, M., 2000. Granulite/charnockite from the Juiz de Fora Domain, central segment of the Brasiliano Ribeira Belt. Rev. Bras. Geociências 30, 358-362.

Farina, F., Stevens, G., Dini, A., Rocchi, S., 2012. Peritectic phase entrainment and magma mixing in the late Miocene Elba Island laccolith-pluton-dyke complex (Italy). Lithos 153, 243-260.

Féboli, W.L., 2000. Folha Governador Valadares. Projeto Leste. CPRM-CODEMIG. http://www.portalgeologia.com.br/mapa/.

Féboli, W.L., Paes, V.C., 2000. Folha Itanhomi. Projeto Leste. CPRM-CODEMIG. http:// www.portalgeologia.com.br/mapa/.

Figueiredo, M.C.H., Campos Neto, M.C., 1993. Geochemistry of the Rio doce magmatic arc, Southeastern Brazil. An. Acad. Bras. Ciências 65, 63-81.

Figueiredo, C.M. de S., 2009. O Arco Magmático Brasiliano na Conexão entre os Orógenos Araçuaí e Ribeira, Região de Muriaé - MG. Master Thesis. Universidade Federal de Minas Gerais, Brazil, p. 88.

Figueiredo, M.C.H., Teixeira, W., 1996. The Mantiqueira metamorphic complex, eastern minas gerais state: preliminary geochronological and geochemical results. An. Acad. Bras. Ciências 68, 223-246.

Fischel, D.P., Pimentel, M.M., Fuck, R.A., Costa, A.G., Rosière, C.A., 1998. Geology and Sm-Nd isotopic data for the Mantiqueira and Juiz de Fora complexes (Coastal Mobile belt) in the Abre Campo region, Minas Gerais, Brazil. In: International Conference on Precambrian and Cratonic Tectonics. Universidade Federal de Ouro Preto, Ouro Preto, Brazil, pp. 21-23.

Frost, B.R., Frost, C.D., 2008. On charnockites. Gondwana Res. 13, 30-44.

Frost, B.R., Frost, C.D., Touret, J.L.R., 1989. Magmas as a source of heat and fluids in granulite metamorphism. In: Bridgwater, D. (Ed.), Fluid Movements-Element Transport and the Composition of the Deep Crust, NATO ASI Series V.C-281, pp. $1-18$.

Frost, B.R., Arculus, R.J., Barnes, C.G., Collins, W.J., Ellis, D.J., Frost, C.D., 2001. A geochemical classification of granitic rocks. J. Petrol. 42, 2033-2048.

Glazner, A.F., 2007. Thermal limitations on incorporation of wall rock into magma. Geology 35, 319-322.

Gonçalves, L.E. da. S., 2009. Características Gerais e História Deformacional da Suíte Granítica G1, entre Governador Valadares e Ipanema, MG. Master Thesis. Universidade Federal de Ouro Preto, Ouro Preto, Brasil, p. 112.

Gonçalves, L. E. da S., Alkmim, F.F., Pedrosa-Soares, A.C., 2010. Características geoquímicas da Suíte G1, arco magmático do Orógeno Araçuaí, entre Governador Valadares e Ipanema, MG. Rev. Esc. Minas 63, 457-464.

Heilbron, M., Duarte, B., Valeriano, C., Simonetti, A., Machado, N., Nogueira, J., 2010 Evolution of reworked Paleoproterozoic basement rocks within the Ribeira belt (Neoproterozoic), SE-Brazil, based on U Pb geochronology: implications for paleogeographic reconstructions of the São Francisco-Congo paleocontinent. Precambrian Res. 178, 136-148.

Klötzli, U., Klötzli, E., Günes, Z., Kosler, J., 2009. Accuracy of laser ablation U-Pb zircon dating: results from a Test using five different reference zircons. Geostand. Geoanalyt. Res. 33, 5-15.

Kracek, F.C., Neuvonen, K.J., 1952. Thermochemistry of plagioclase and alkali feldspars. Am. J. Sci. Bowen Vol., 293-318.

Machado, N., Valladares, C., Heilbron, M., Valeriano, C., 1996. U-Pb geochronology of the central Ribeira belt (Brazil) and implications for the evolution of the Brazilian Orogeny. Precamb. Res. 69, 347-361.

Martins, V. T. de S., Teixeira, W., Noce, C.M., Pedrosa-Soares, A.C., 2004. Sr-Nd characteristics of Brasiliano/Pan-Africano granitoid plutons of the Araçuaí Orogen, Southeastern Brazil: tectonic implications. Gondwana Res. 7, 75-89.

Mondou, M., Egydio-Silva, M., Vauchez, A., Raposo, M.I.B., Bruguier, O., Oliveira, A.F., 2012. Complex, 3D strain patterns in a synkinematic tonalite batholith from the Araçuaí Neoproterozoic orogen (Eastern Brazil): evidence from combined magnetic and isotopic chronology studies. J. Struct. Geol. 39, 158-179.

Nakamura, N., 1974. Determination of REE, Ba, Fe, Mg, Na and K in carbonaceous and ordinary chondrites. Geochim. Cosmochim. Acta 38, 757-775.

Nalini Jr., H.A., 1997. Caractérisation des suites magmatiques néoprotérozoiques de la region de Conselheiro Pena et Galiléia (Minas Gerais, Brésil). Etude géochimique et structurale des suites Galiléia et Urucum et relations avec les pegmatites à éléments rares associées. Ph.D. Thesis. Ecole des Mines de Saint Etienne et Ecole des Mines de Paris, p. 237.

Nalini Jr., H.A., Bilal, E., Correia Neves, J.M., 2000. Syn-collisional peraluminous magmatism in the Rio Doce region: mineralogy, geochemistry and isotopic data of the Urucum suite (eastern Minas Gerais state, Brazil). Rev. Bras. Geociências 30, 120-125.

Nalini Jr., H.A., Machado, R., Bilal, E., 2005. Geoquímica e Petrogênese da Suíte Galiléia: Exemplo de Magmatismo Tipo-I Metaluminoso Pré-Colisional Neoproterozóico da Região do Médio Vale do Rio Doce (MG). Rev. Bras. Geociências 35, 23 -34.

Noce, C.M., Costa, A.G., Piuzana, D., Vieira, V.S., Carvalho, C., 2006. Geologia da Folha Manhuaçu 1:100,000. UFMG - CPRM, GEOBANK. www.cprm.gov.br.

Noce, C.M., Pedrosa-Soares, A.C., Silva, L.C., Armstrong, R., Danielle Piuzana, D., 2007. Evolution of polycyclic basement complexes in the Araçuaí Orogen, based on U-Pb SHRIMP data: implications for Brazil-Africa links in Paleoproterozoic time. Precambrian Res. 159, 60-78.

Noce, C.M., Novo, T., Figueiredo, C., Pedrosa-Soares, A.C., 2012. Geologia da Folha Carangola 1:100,000. UFMG - CPRM, GEOBANK. www.cprm.gov.br.
Novo, T.A., 2009. Significado geotectônico das rochas charnockíticas da região de Carangola: implicações para a conexão Araçuaí-Ribeira. Master Thesis. Universidade Federal de Minas Gerais, Belo Horizonte, Brasil, p. 87.

Novo, T.A., 2013. Caracterização do Complexo Pocrane, Magmatismo Básico Mesoproterozóico e Unidades Neoproterozóicas do Sistema Araçuaí-Ribeira, com ênfase em Geocronologia U-Pb (SHRIMP e LA-ICP-MS). Ph.D Thesis. UFMG, Belo Horizonte, Brazil, p. 193.

Novo, T.A., Pedrosa-Soares, A.C., Noce, C.M., Alkmim, F.F., Dussin, I., 2010. Rochas charnockíticas do sudeste de Minas Gerais: a raiz granulítica do arco magmático do Orógeno Araçuaí. Rev. Bras. Geociências 40, 573-592.

Oliveira, M.J.R., 2000. Folha Conselheiro Pena. Projeto Leste. CPRM-CODEMIG. http://www.portalgeologia.com.br/mapa/.

Paes, V.J. de C., 1999. Geologia e Geoquímica da Região de Alvarenga, Minas Gerais: implicações geotectônicas e metalogenéticas. Master Thesis. Universidade Federal de Minas Gerais, Belo horizonte, Brasil, p. 149.

Pedrosa-Soares, A.C., Wiedemann-Leonardos, C.M., 2000. Evolution of the Araçuaí belt and its connection to the Ribeira Belt, Eastern Brazil. In: Cordani, U.G., Milani, E.J., Thomaz Filho, A., Campos, D.A. (Eds.), Tectonic Evolution of South America. International Geological Congress, Rio de Janeiro, pp. 265-285.

Pedrosa-Soares, A.C., Noce, C.M., Vidal, P., Monteiro, R.L.B.P., Leonardos, O.H., 1992. Toward a new tectonic model for the Late Proterozoic Araçuaí (SE Brazil) West Congolian (SW Africa) Belt. J. South Am. Earth Sci. 6, 33-47.

Pedrosa-Soares, A.C., Vidal, P., Leonardos, O.H., Brito-Neves, B.B., 1998. Neoproterozoic oceanic remnants in eastern Brazil: further evidence and refutation of an exclusively ensialic evolution for the Araçuaí-West Congo Orogen. Geology 26, 519-522.

Pedrosa-Soares, A.C., Noce, C.M., Wiedemann, C.M., Pinto, C.P., 2001. The AraçuaíWest Congo orogen in Brazil: an overview of a confined orogen formed during Gondwanland assembly. Precamb. Res. 110, 307-323.

Pedrosa-Soares, A.C., Alkmim, F.F., Tack, L., Noce, C.M., Babinski, M., Silva, L.C., Martins-Neto, M.A., 2008. Similarities and Differences between the Brazilian and African Counterparts of the Neoproterozoic Araçuaí-West-Congo Orogen. Geological Society, London, pp. 153-172. Special Publications 294.

Pedrosa-Soares, A.C., De Campos, C., Noce, C.M., Silva, L.C., Novo, T., Roncato, J., Medeiros, S., Castañeda, C., Queiroga, G., Dantas, E., Dussin, I., Alkmim, F.F., 2011. Late Neoproterozoic-Cambrian Granitic Magmatism in the Araçuaí Orogen (Brazil), the Eastern Brazilian Pegmatite Province and Related Mineral Resources. Geological Society, London, pp. 25-51. Special Publications 350 .

Pereira, L.M.M., Zucchetti, M., 2000. Projeto Leste: Petrografia. Relatório Integrado. Etapa II. CPRM/CODEMIG, Belo Horizonte, Brazil, p. 96.

Petitgirard, S., Vauchez, A., Egydio-Silva, M., Bruguier, O., Campos, P., Monié, P., Babinski, M., Mondou, M., 2009. Conflicting structural and geochronological data from the Ibituruna quartz-syenite (SE Brazil): effect of protracted "hot" orogeny and slow cooling rate? Tectonophysics 477, 174-196.

Pitcher, W.S., 1991. Synplutonic dykes and mafic enclaves. In: Didier, J., Barbarin, B. (Eds.), Enclaves and Granite Petrology. Elsevier Science Publishers B. V, Amsterdam, pp. 383-391.

Pitcher, W.S., 1997. The Nature and Origin of Granite, second ed. Chapman \& Hall, London, p. 377.

Ribeiro, J.H., 2000. Folha Dom Cavati. Projeto Leste. CPRM-CODEMIG. http://www. portalgeologia.com.br/mapa/.

Rickwood, P.C., 1989. Boundary lines within petrologic diagrams which use oxides of major and minor elements. Lithos 22, 247-263.

Rogers, J.W., Santosh, M., 2004. Continents and Supercontinents. Oxford University Press, p. 289.

Signorelli, N., 2000. Folha Caratinga. Projeto Leste. CPRM-CODEMIG. http://www. portalgeologia.com.br/mapa/.

Silva, L.C., Armstrong, R., Noce, C.M., Carneiro, M., Pimentel, M., Pedrosa-Soares, A.C., Leite, C., Vieira, V.S., Silva, M., Paes, V., Cardoso-Filho, J., 2002. Reavaliação da evolução geológica em terrenos pré-cambrianos brasileiros com base em novos dados U-Pb SHRIMP, parte II: Orógeno Araçuaí, Cinturão Móvel Mineiro e Cráton São Francisco Meridional. Rev. Bras. Geociências 32, 513-528.

Silva, L.C., McNaughton, N.J., Armstrong, R., Hartmann, L., Fletcher, I., 2005. The Neoproterozoic Mantiqueira Province and its African connections: a zirconbased $\mathrm{U}-\mathrm{Pb}$ geochronologic subdivision for the Brasiliano/Pan-African systems of orogens. Precambrian Res. 136, 203-240.

Silva, L.C., Pedrosa-Soares, A.C., Armstrong, R., Noce, C.M., 2011. Determinando a duração do período colisional do Orógeno Araçuaí com base em geocronologia $\mathrm{U}-\mathrm{Pb}$ de alta resolução em zircão: uma contribuição para a história da amalgamação do Gondwana Ocidental. Geonomos 19, 180-197.

Skjerlie, K.P., Patiño Douce, A.E., 1995. Anatexis of interlayered amphibolite and pelite at 10 kbar: effect of diffusion of major components on phase relations and melt fraction. Contrib. Mineral. Petrol. 122, 62-78.

Sláma, J., Košler, J., Condon, D.J., Crowley, J.L., Gerdes, A., Hanchar, J.M., Horstwood, M.S.A., Morris, G.A., Nasdala, L., Norberg, N., Schaltegger, U., Schoene, B., Tubrett, M.N., Whitehouse, M.J., 2008. Plešovice zircon - a new natural reference material for $\mathrm{U}-\mathrm{Pb}$ and $\mathrm{Hf}$ isotopic microanalysis. Chem. Geol. 249, 1-35.

Stevens, G., Clemens, J.D., Droop, G.T.R., 1997. Melt production during granulitefacies anatexis: experimental data from "primitive" metasedimentary protoliths. Contrib. Mineral. Petrol. 128, 352-370.

Tedeschi, M., 2013. Caracterização do arco magmático do Orógeno Araçuaí entre Frei Inocêncio e Itambacuri, MG. Master Thesis. UFMG, Belo Horizonte, Brazil, p. 127. 
Trompette, R., 1994. Geology of Western Gondwana (2000-500 Ma). In: Pan-African/Brasiliano Aggregation of South America and Africa. A.A. Balkema, Rotterdam, p. 350.

Tuller, M., 2000. Folha Ipanema. Projeto Leste. CPRM-CODEMIG. http://www. portalgeologia.com.br/mapa/.

van Achterbergh, E., Ryan, C.G., Jackson, S.E., Griffin, W., 2001. Data reduction software for LA744 ICP-MS. In: Sylvester, P. (Ed.), Laser Ablation ICPMS in the Earth Science, vol. 29. Mineralogical 745 Association of Canada, pp. 239-243.

Vieira, V.S., 1993. Folha Baixo Guandu. CPRM, Programa Levantamentos Geológicos Básicos do Brasil, Belo Horizonte.
Vieira, V.S., 2000. Folha Itabitinha de Mantena. Projeto Leste. CPRM-CODEMIG http://www.portalgeologia.com.br/mapa/.

Vieira, V.S., 2007. Significado do Grupo Rio Doce no Contexto do Orógeno Araçuaí. Ph.D. Thesis. IGC-UFMG, Belo Horizonte, Brasil, p. 117.

Wilson, M., 1989. Igneous Petrogenesis. A Global Tectonic Approach. Unwin Hyman, London, p. 466.

Young, D.N., Zhao, J.-X., Ellis, D.J., McCulloch, M.T., 1997. Geochemical and Sr-Nc isotopic mapping of source provinces for the Mawson charnockites, east Antarctica: implications for Proterozoic tectonics and Gondwana reconstruction. Precambrian Res. 86, 1-19. 